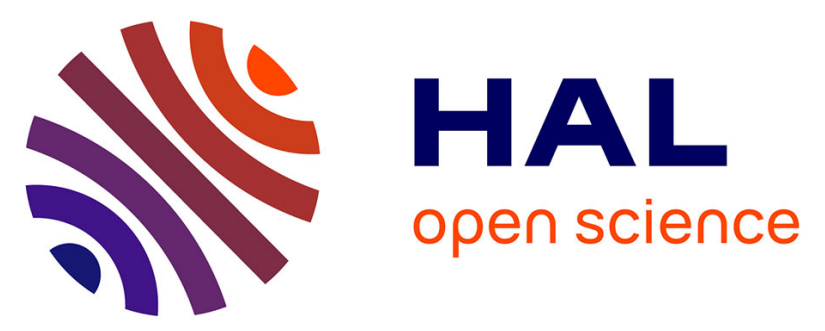

\title{
Steps of Morphogenesis and Iterative Evolution of Imperforate Larger Foraminifera in Shallow Carbonate Shelves During Mesozoic Times: Possible Relations to Symbiotic and Abiotic Factors
}

Michel Septfontaine

\section{To cite this version:}

Michel Septfontaine. Steps of Morphogenesis and Iterative Evolution of Imperforate Larger Foraminifera in Shallow Carbonate Shelves During Mesozoic Times: Possible Relations to Symbiotic and Abiotic Factors. Morphogenesis, Environmental Stress and Reverse Evolution, Springer International Publishing, pp.129-173, 2020, 10.1007/978-3-030-47279-5_8 . hal-02940987

\section{HAL Id: hal-02940987 \\ https://hal.science/hal-02940987}

Submitted on 16 Sep 2020

HAL is a multi-disciplinary open access archive for the deposit and dissemination of scientific research documents, whether they are published or not. The documents may come from teaching and research institutions in France or abroad, or from public or private research centers.
L'archive ouverte pluridisciplinaire HAL, est destinée au dépôt et à la diffusion de documents scientifiques de niveau recherche, publiés ou non, émanant des établissements d'enseignement et de recherche français ou étrangers, des laboratoires publics ou privés. 


\section{Metadata of the chapter that will be visualized online}

\begin{tabular}{lll}
\hline Chapter Title & $\begin{array}{l}\text { Steps of Morphogenesis and Iterative Evolution of Imperforate Larger Foraminifera } \\
\text { in Shallow Carbonate Shelves During Mesozoic Times: Possible Relations } \\
\text { to Symbiotic and Abiotic Factors }\end{array}$ \\
\hline $\begin{array}{l}\text { Copyright Year } \\
\text { Copyright }\end{array}$ & Springer Nature Switzerland AG & \\
Holder & & Septfontaine \\
\hline $\begin{array}{l}\text { Corresponding } \\
\text { Author }\end{array}$ & Family Name & \\
& Particle & Michel \\
& Given Name & \\
& Suffix & \\
& Division & Independent researcher (retired) \\
& Organization/University & Froideville, Switzerland \\
Address & septfontaine.m@ bluewin.ch \\
Email &
\end{tabular}




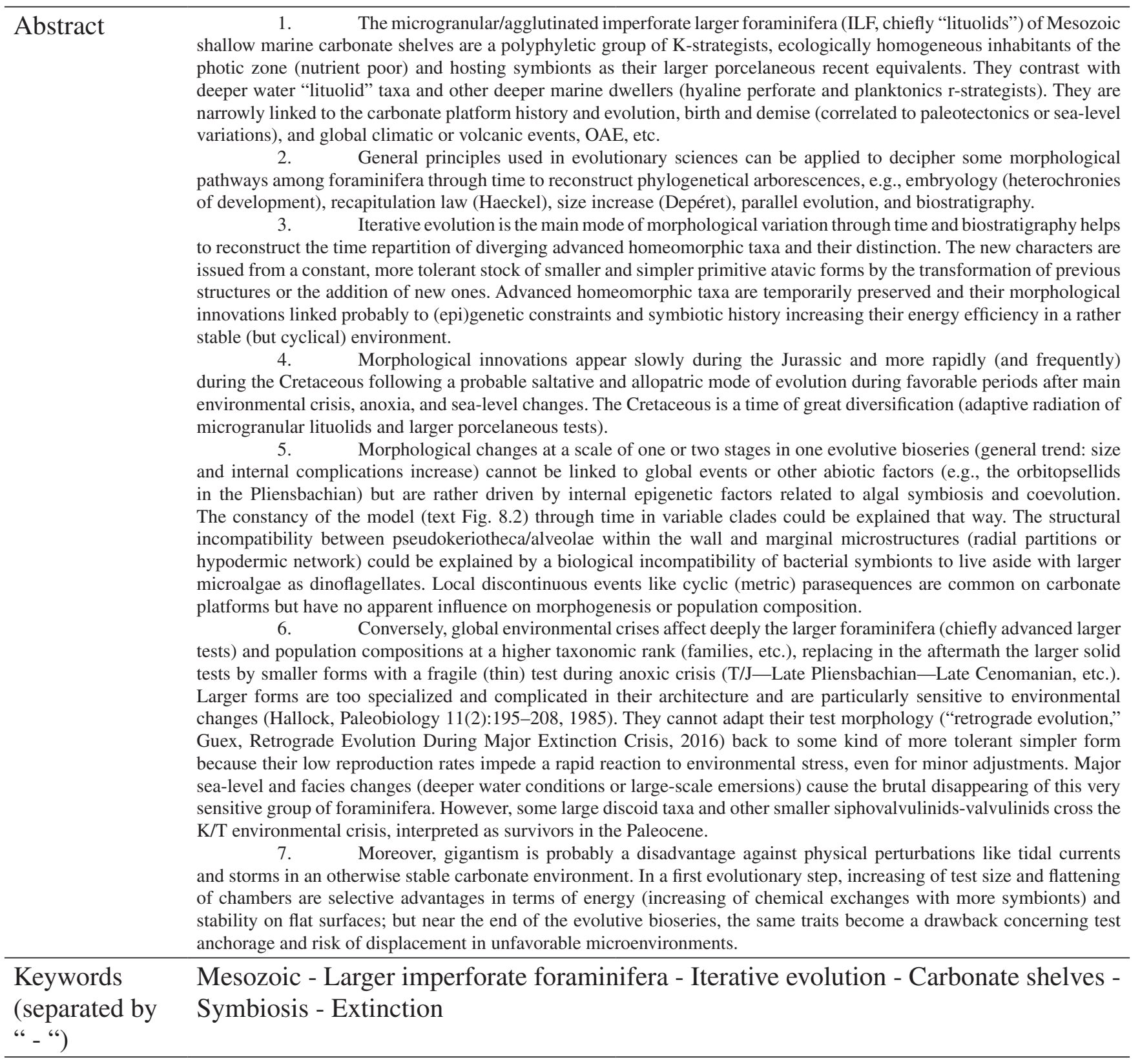




\section{Chapter 8}

Steps of Morphogenesis and Iterative

\section{Abstract}

1. The microgranular/agglutinated imperforate larger foraminifera (ILF, chiefly "lituolids") of Mesozoic shallow marine carbonate shelves are a polyphyletic group of K-strategists, ecologically homogeneous inhabitants of the photic zone (nutrient poor) and hosting symbionts as their larger porcelaneous recent equivalents. They contrast with deeper water "lituolid" taxa and other deeper marine dwellers (hyaline perforate and planktonics r-strategists). They are narrowly linked to the carbonate platform history and evolution, birth and demise (correlated to paleotectonics or sea-level variations), and global climatic or volcanic events, OAE, etc.

2. General principles used in evolutionary sciences can be applied to decipher some morphological pathways among foraminifera through time to reconstruct phylogenetical arborescences, e.g., embryology (heterochronies of development), recapitulation law (Haeckel), size increase (Depéret), parallel evolution, and biostratigraphy.

3. Iterative evolution is the main mode of morphological variation through time and biostratigraphy helps to reconstruct the time repartition of diverging advanced homeomorphic taxa and their distinction. The new characters are issued from a constant, more tolerant stock of smaller and simpler primitive atavic forms by the transformation of previous structures or the addition of new ones. Advanced homeomorphic taxa are temporarily preserved and their morphological innovations linked probably to (epi)genetic constraints and symbiotic history increasing their energy efficiency in a rather stable (but cyclical) environment.

4. Morphological innovations appear slowly during the Jurassic and more rapidly (and frequently) during the Cretaceous following a probable saltative and allo- 
patric mode of evolution during favorable periods after main environmental crisis, anoxia, and sea-level changes. The Cretaceous is a time of great diversification (adaptive radiation of microgranular lituolids and larger porcelaneous tests).

5. Morphological changes at a scale of one or two stages in one evolutive bioseries (general trend: size and internal complications increase) cannot be linked to global events or other abiotic factors (e.g., the orbitopsellids in the Pliensbachian) but are rather driven by internal epigenetic factors related to algal symbiosis and coevolution. The constancy of the model (text Fig. 8.2) through time in variable clades could be explained that way. The structural incompatibility between pseudokeriotheca/alveolae within the wall and marginal microstructures (radial partitions or hypodermic network) could be explained by a biological incompatibility of bacterial symbionts to live aside with larger microalgae as dinoflagellates. Local discontinuous events like cyclic (metric) parasequences are common on carbonate platforms but have no apparent influence on morphogenesis or population composition.

6. Conversely, global environmental crises affect deeply the larger foraminifera (chiefly advanced larger tests) and population compositions at a higher taxonomic rank (families, etc.), replacing in the aftermath the larger solid tests by smaller forms with a fragile (thin) test during anoxic crisis (T/J-Late Pliensbachian-Late Cenomanian, etc.). Larger forms are too specialized and complicated in their architecture and are particularly sensitive to environmental changes (Hallock, Paleobiology 11(2):195-208, 1985). They cannot adapt their test morphology ("retrograde evolution," Guex, Retrograde Evolution During Major Extinction Crisis, 2016) back to some kind of more tolerant simpler form because their low reproduction rates impede a rapid reaction to environmental stress, even for minor adjustments. Major sea-level and facies changes (deeper water conditions or large-scale emersions) cause the brutal disappearing of this very sensitive group of foraminifera. However, some large discoid taxa and other smaller siphovalvulinids-valvulinids cross the $\mathrm{K} / \mathrm{T}$ environmental crisis, interpreted as survivors in the Paleocene.

7. Moreover, gigantism is probably a disadvantage against physical perturbations like tidal currents and storms in an otherwise stable carbonate environment. In a first evolutionary step, increasing of test size and flattening of chambers are selective advantages in terms of energy (increasing of chemical exchanges with more symbionts) and stability on flat surfaces; but near the end of the evolutive bioseries, the same traits become a drawback concerning test anchorage and risk of displacement in unfavorable microenvironments.

Keywords Mesozoic - Larger imperforate foraminifera - Iterative evolution · Carbonate shelves $\cdot$ Symbiosis $\cdot$ Extinction 


\subsection{Introduction}

Recent larger foraminifera (fusiform alveolinids and discoidal porcelaneous forms as Sorites, Amphisorus, and Marginopora) in shallow warm waters of low latitudes were extensively studied during the twentieth century. They can serve as references or living models for extinct microgranular-agglutinant imperforate larger foraminifera (ILF) with a similar general morphology on carbonate platforms submitted to a sub- to supratidal cyclical (parasequences) type of environment considered here as "stable". Recent equivalent morphotypes are epiphytic as the discoid porcelaneous genus Sorites (Richardson 2009) or live in coarse calcareous sands associated with reef buildups and other carbonate depositional environments (ramps or restricted lagoons in rare cases).

Most genera host symbiotic microorganisms, e.g., nitrifying bacteria, nonphotosynthetic, for the agglutinating Spiculidendron in shaded fore-reef habitats (Richardson and Rützler 1999), algae, dinoflagellates, and diatoms in shallower waters for porcelaneous or hyaline taxa. The symbionts are free living in the endoplasmic cell, or stocked, densely packed, in chamberlets near the surface of the translucid calcareous test (Hallock 1982, 1985; Richardson 2006). These authors give a general review of previous studies on this vast subject, illustrating that algal symbiosis is energetically highly advantageous under nutrient-deficient (oligotrophic) conditions, as is the case in hermatypic coral reefs (or bivalve mounds) environments. Thus, larger shells, hosting numerous symbionts, are advantageous in stable environments with restricted food resources. Hallock (1985) notes that, already in the 1970s, Ross (1974) and Lee et al. (1979) "have postulated that evolution in larger Foraminifera is related to adaptation to algal symbiosis." These conclusions based on the modern (porcelaneous) equivalents of fossil imperforate larger microgranular-agglutinated foraminifera (ILF) can serve as a guide for the understanding of the complex (iterative) morphogenetical evolution of this group of microorganisms during Jurassic and Cretaceous times.

However, general palaeogeographical and environmental conditions, even on carbonate shallow platforms in the past, were notably different from the recent, particularly in terms of size (width and length) along the tropical-equatorial belt (e.g., about $8000 \mathrm{~km}$ from Morocco to Mexico to the west or Oman and Iran to the east). In spite of the huge extension of Mesozoic carbonate platforms along the southern margin of the Tethys, most assemblages (and isolated genera) can be considered as synchronous on each location of this domain, except local migrations in some restricted areas, like the protected eutrophic lagoon of the "Mytilus beds" in the Briançonnais domain till Sardinia (Septfontaine 1984a).

Moreover, Jurassic and Cretaceous "lituolids" have developed complex original inner microstructures (from the Liassic onwards) that are not known in the Tertiary and in recent taxa. Thus, maximum caution must be taken when comparing and trying to decipher the function of such microstructures (Hottinger 2006) and their role in the individual life of the foraminifera, and more generally the relation (epigenetic or genetic trend in a stable environment) with the past biotopes in an evolutionary 
perspective, deduced only from morphological characters. On the other hand, as stated above, symbiosis is an important mechanism of evolution in the diversification of eukaryotic clades, and this form of coevolution is widespread in all taxa of the foraminifera (Brasier 1988; Richardson and Rützler 1999).

Delayed maturation and growth to large size (K-strategist bearing symbiotic microorganisms or "greenhouse" management) are only advantageous under stable conditions where resources are limited (Hallock 1985). But a rapid change of environmental factors (anoxia, temperature, acidity, water depth during sea-level drop or rise, etc.) will doom the giant cell with its symbionts to extinction. Moreover, some morphological limitation of size and complexity related to physical environmental conditions (hydrological instabilities due to tidal currents, storms) may play an important role regarding the fixation of the large tests on different substrates.

\subsection{Summary of General Principles}

Some basic principles in evolutionary sciences can help and guide the reconstruction of phyletic arborescences. They were already discussed by Septfontaine (1988), as a working hypothesis, with some additions in the field of geology, stratigraphy, and sedimentology. These principles are classical and were already used for Metazoa. An application for eukaryotic Protozoa seems reasonable, keeping in mind possible exceptions; this approach completes the classical cladistic-phylogenetic (morphological) method in biology (Hennig 1966; Lecointre and Le Guyader 2001). Obviously, the advantage of defining principles is that they can easily be refuted or at least modified!

1st Principle: The phyletic relations are to be found exclusively among the stock of paleoecologically specialized dwellers of shallow carbonate platforms (in the photic zone), from the protected lagoonal environment to the outer platform and fore-reef talus. The ancestors of each group (if polyphyletic) are to be found in these depositional environments (excluding the open marine basinal environments) and are necessarily small with a simple morphology; they can be sometimes recognized in the first ontogenetic steps of the test (nepionic stage) of more evoluted individuals.

2nd Principle: The stratigraphic and paleogeographic repartition of genera during Mesozoic times (Septfontaine 1981, 1988; Bassoullet 1997) allows identification of the homeomorphic taxa (in one individual clade). Each morphological novelty is rapidly widespread all along the tropical belt in $\mathrm{N}$ and $\mathrm{S}$ margins of the Thetysian domain (cosmopolitan genera), and no true endemism is known. Local absence is due to facies changes. In some cases (e.g., the Briançonnais domain, $\mathrm{N}$ margin with restricted eutrophic conditions) steps of migrations were observed in the lagoon (Septfontaine 1984a).

3rd Principle: Genetic proximity is deduced from the morphological closeness of characters through space and time (cladistic approach), basically the only possible method in paleontology with the risk to gather parallel isomorphic clades of different origins. The "weight" of characters should be estimated: presupposed 
minor or secondary characters may be of prime importance. The morphological variations (shape of chambers and contour of the test) in a given synchronous and abundant population (displaced tests recognized in tempestites or turbidites, an instant mechanism, Fig. 8.1) give a picture of the possible variations of that species through time as resumed horizontally and vertically in the general virtual model text; see Fig. 8.2. The model is shared by different clades of microgranular - imperforate foraminifera, and probably by isomorphic porcelaneous or hyaline - perforate larger discoid taxa (convergences and parallel evolution, MacGillavry 1978) in a similar environment.

4th Principle: Ontogenesis and heterochrony in individual developmental steps, combined with delayed maturation (Gould 1977; Chaline 1987), are considerable and simple means of morphogenetic innovations from existing structures to new ones via minor genetic mutations (neoteny, progenesis, or acceleration). The test of foraminifera, built by incrementation of successive chambers, can retain (or not) the atavic morphology in early steps of ontogenesis in some advanced taxa (recapitulation law). This particularity permits to decipher the phylogenetic history of some advanced clades.

5th Principle: The role of sedimentary sequential evolution in carbonate platforms (from parasequences to third-order sequences) regarding morphogenesis or assem-

156

157

158

159

160

161

162

163

164

165

166

167

168

169

170

171

172

173

174

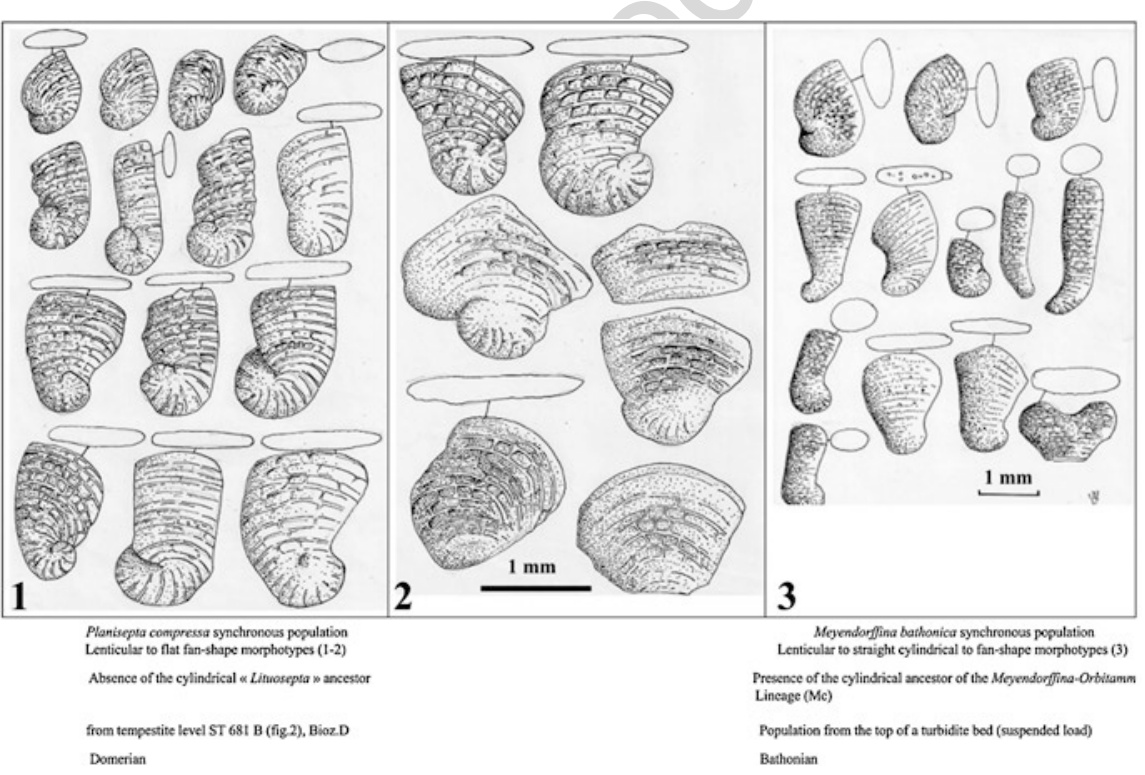

Fig. 8.1 Synchronous populations. 1-2: in a sample with Planisepta compressa from a tempestite level (Middle Liassic of Morocco); 3: in a sample with Meyendorffina bathonica (Bathonian of Swiss Prealps). The shape diversity (lenticular to flabelliform-reniform, with flattening of tests) is similar to a recent porcelaneous population of Peneroplis pertusus (Hottinger 2006). These contemporaneous morphotypes give a spectrum of possible variations of shape through time, as depicted in Fig. 8.2 for the genus Orbitopsella 

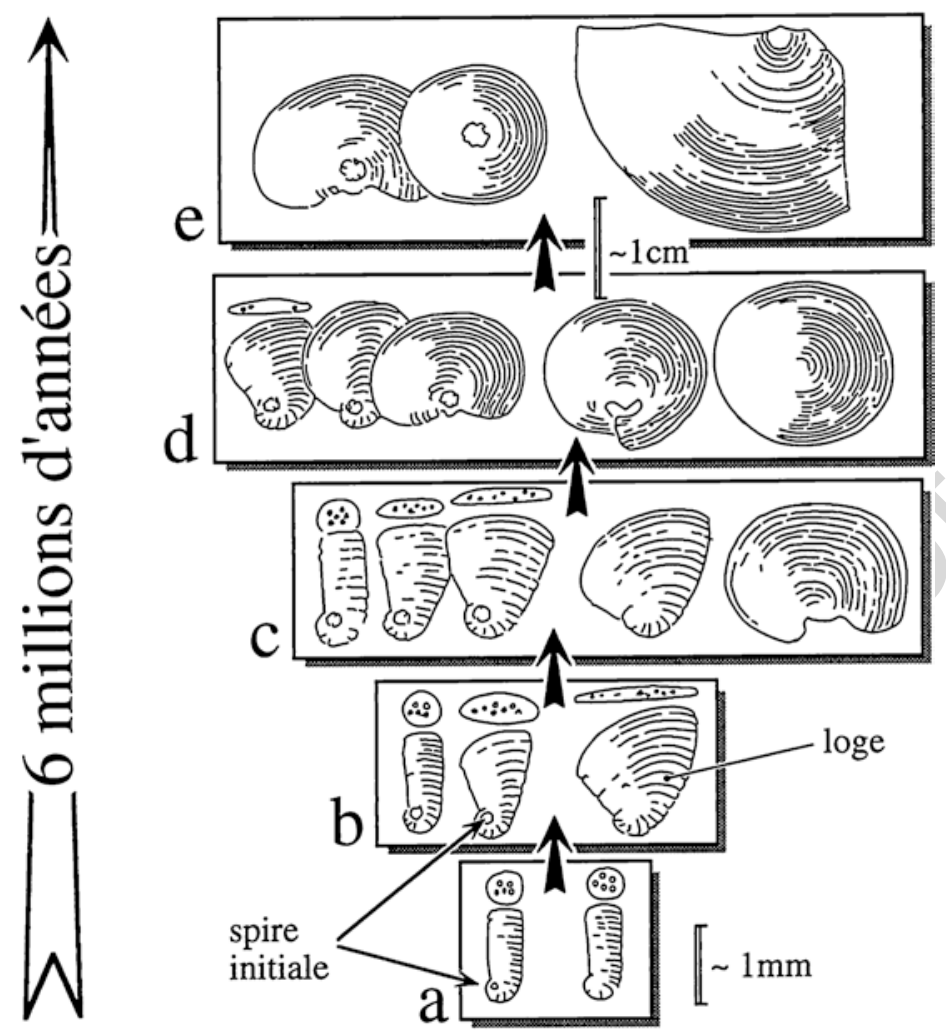

Fig. 8.2 Excerpt from Septfontaine (1988). Virtual phylogenetical model of Mesozoic larger discoid foraminifera (microgranular-agglutinated and porcelaneous) based on observations of evolutionary trends in the mesoendothyrids and orbitopsellids s.l. (Mesoendothyra-LituoseptaOrbitopsella) of Morocco (from Late Sinemurian to Carixian; Septfontaine 1984b, 1988) and Mallorca. The last morphological steps (e) of the K-strategist giant cell disappear in a constant environment far below the beginning of the T-OAE crisis starting in Late Domerian (see also Table 8.6). Some internal factors, as a deleterious relation with symbiotic algae or a mechanical incompatibility of the large discoid shell regarding stability and attachment to the substrate (pseudopods through limited openings), may explain the disappearance of the population. The stratigraphical and sedimentological general setting should allow distinguishing between a time control (vertical) and a facies control (horizontal, "epigenetic," a-e) of the morphogenesis. Population biodiversity (and trend) is marked by chamber flattening and enlargement The model has been observed in several Jurassic clades like the bioseries: Amijiella-Alzonella; Haurania-Timidonella; Meyendorffina-Orbitammina, etc. or Cretaceous bioseries: CuneolinaDicyclina and some others (Table 8.2)

Macrospherical individuals are to the left (rounded large embryo); microspherical reniform to discoidal tests to the right. Note that in very advanced populations (Orbitopsella dubari or Cyclorbitopsella) the chambers of macrospheric individuals are completely cyclical 
blages of foraminifera can be estimated as well as their importance (or not) in disappearance or changes of populations (turnovers); sedimentological studies allow evidence for population composition or concentration due to sorting, reworking, or displacement of empty tests by currents or hurricanes (Septfontaine 1985; Davaud and Septfontaine 1995), all bias influencing paleoecological conclusions.

6th Principle: Morphogenesis of microstructures in the wall (pseudokeriotheca and alveolae) or in the marginal zone of the chambers (hypodermic network or radial partitions defining chamberlets) can be tentatively related to symbiosis with microorganisms and their coevolution with the foraminiferal cell: filamentous cyanobacteria (keriotheca of fusulinids in Vachard et al. 2004), diatoms, dinoflagellates, or other microalgae.

\subsection{Incompleteness of the Fossil Record on Carbonate Platforms Impedes Evolutionary Studies: A Situation Linked to the Unstable Environmental Context (Hiatuses, Emersions, and Drownings)}

The imperforate larger foraminifera on shallow carbonate platforms represent a particularly difficult group of microfossils to deal with for evolutionary and morphogenetical studies and interpretation, unlike the open marine planktonic foraminifera or radiolarians with a larger and more continuous record, as discussed by Guex (2016). The author introduces a new model of "retrograde evolution" in the Cretaceous rotaliporiids, well documented during the Cenomanian anoxic crisis. The main practical reasons (rarely invoked since Darwin 1859) that impede the comprehension of the mode of evolution (reverse, progressive versus saltative, etc.) and morphogenetical history of ILF are listed below and must be kept in mind:

1. It is not possible to consider a rather sufficient large population (and its morphological variations, principle 5 above) at a given level (generally from a hard rock sample) because of a rather poor abundance related to their mode of reproduction (K-strategists with a low reproduction rate compared to the r-strategist planktonics in one bed). Thus the number of morphotypes yielded for estimation of morphological variation and plasticity is commonly poor. In the Mesozoic interval, larger foraminifera are studied in thin sections, or scarcely as loose specimens extracted from shaly levels.

2. Their vertical (stratigraphical) occurrence in outcrops is generally episodical and the populations available are rather poor in individuals except for some intervals (top of parasequences in inter- to supratidal environments with an accumulation of dead transported tests by the tide, hurricanes, etc.) (Fig. 8.3, and Septfontaine 1985). This situation is classical in the Mesozoic carbonates along the southern and northern margins of the alpine and eastern Tethys. Obviously, the lack of continuity in sedimentation and major environmental changes related to paleotectonics and orbital cyclicity (emersions and hiatuses, Bosence et al. 2009; 


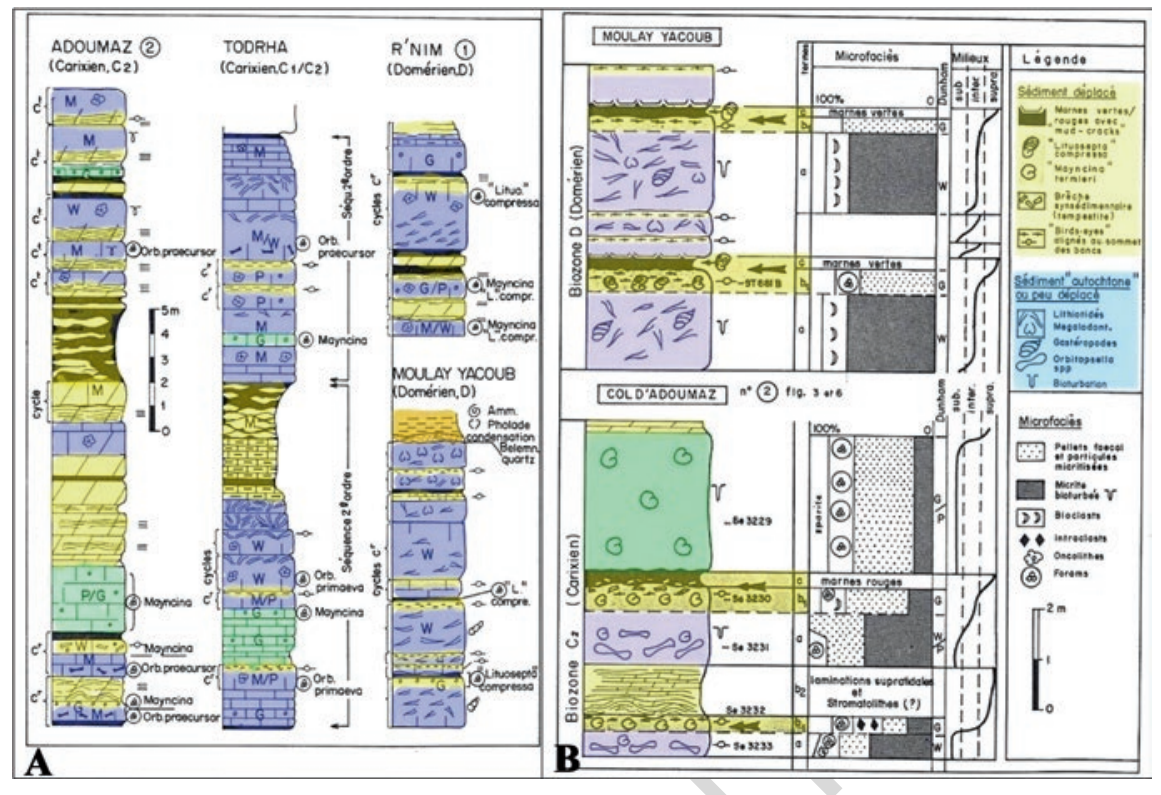

Fig. 8.3 (A) The Aganane formation (Pliensbachian) in different locations of the High Atlas and Rif foreland (Moulay Yacoub) in Morocco. (B) Detail of metric "shallowing upward" parasequences and storm beds (in green). This cyclical type of deposit, in the photic zone, is widespread in space and time along the southern margin of the Mesozoic Neotethys carbonate shelves from Morocco to Oman (via Italy and the Dinarids) and on the northern margin in Mallorca or Sardinia. These depositional conditions represent the general sedimentological setting where imperforate larger foraminifera (ILF) live and evolve, a rather unstable environment characterized by rapid and multiple (metric to decametric) sea-level changes, emersions, etc. Paradoxically, this environmental instability does not influence the morphogenetic variability, obviously depending on other factors like symbiotic coevolution. Important abiotic factors driving to microfaunal extinction or turnover are anoxia (Table 8.6) and global drowning

Figures excerpt from Septfontaine (1985)

Strasser (2016), versus drowning and deepwater conditions) explain the episodical and scarcity of microfossil-rich intervals compared to planktonics. It impedes the study of morphological pathways and diversity in space and time (either of genetic or of ecophenotypic, epigenetic origin) and finally to argue for the evidence of evolutionary trends. However, exceptions are in the liassic carbonates of Morocco (Hottinger 1967; Septfontaine 1985) and will be discussed with the orbitopsellid "plexus" (Fig. 8.2 and Table 8.6).

3. The stratigraphical calibration (e.g., with ammonite biozones) is difficult in particular in the eastern Tethys area, due to the almost absence of any valuable pelagic time marker. Moreover, bioevents are not well marked (rarity of macrofossils) and sequential stratigraphy is useless over long distances because of local paleotectonics in most studied cases (Jura-Briançonnais-Sardinia, Italy, Dinarids, Morocco, Oman, etc.) related to a general situation of the Tethyan 
opening and rifting (and later closing) of the northern and southern margins during the Mesozoic.

\subsection{Taxonomic Considerations: Weight and Hierarchy of Changing Characters-Origin from an Atavic Stock of Simple Forms}

\subsubsection{Review of Characters}

This short review concerns chiefly the group of shallow water foraminifera with an imperforate microgranular-agglutinated wall (with or without pseudokeriotheca) classically designed as "lituolids", most of them housing symbionts (Brasier 1988) in the wall and the marginal structures (Plate 8.1) of the chambers (as recent miliolids) related to the static protoplasm (Hottinger 1967). The presence of these hollow cavities offers relative protection to the symbionts against cytoplasmic movements or disorders. It is an argument for possible symbiotic coevolution forcing morphogenetic changes in a general trend similar to the one resumed in Fig. 8.2, regarding discoid shell shape and apparition of variable microstructures in the marginal zone of the chambers through time. Moreover, the size/volume/surface increase (Dollo, see Guex 2003) plays an important role in bioseries, advanced larger forms hosting more symbionts like recent Cycloclypeus living in deeper waters (Song et al. 1994). Conversely size decreases (and taxa turnover) aftermath anoxic events is a response to unfavorable conditions (Table 8.6). Equivalences of terminology for morphological descriptive terms of internal microstructures by various authors are given by Septfontaine (1981).

1. The wall is of a rather constant composition (secreted $\mathrm{Mg}$-calcite with some agglutinated material) and presents a microstructure of diversely oriented microgranular calcitic rhombs (electron micrographs, Septfontaine 1971; Banner et al. 1991). In rare cases (Meyendorffina, Pseudocyclammina, Pseudoeggerella, etc.), the wall is covered by a fine surficial layer of agglutinated quartz grains. There exists clearly a relationship between the arrangement of non-oriented (isotropic) microstructure and the absence of ornamentation at the surface of the smooth imperforate test covered by a tectum (compared to the hyaline radial calcitic perforate tests of the Rotaliina exhibiting many ornamentations along the sutures, ridges, knobs, etc.). These ornamentations (or their absence) can also be a mea-

\footnotetext{
${ }^{1}$ Lituolacea De Blainville, 1825 in Loeblich and Tappan $(1964,1988)$ [part], incompletely defined in 1988 ("planispirally enrolled in early stage, later may uncoil") as the authors do not include trochospirally enrolled forms throughout the test in their definition. Many genera are grouped in the order Loftusiida by Kaminsky 2014. In the present study, the term "Lituolids" includes only inhabitants of shallow carbonate platforms.
} 
sure of environmental changes related to water depth or periods of anoxic crises (Guex 2016).

In thin sections, the wall shows sometimes the presence of a pseudokeriotheca, a term incompletely defined as "uniform parallel, radial elements covered by some kind of tectum" by Hottinger (2006). This microstructure is indeed morphologically very close to the analogous keriotheca of fusulinids and endothyrids (Rigaud et al., 2014), but arranged on one row only (see also a review of terminology already discussed in Septfontaine (1981)); the interpretation as tiny tubules $(5 \mu)$ covered by a tectum (Banner et al. 1991) seems obvious (Plate 8.1 (1-6)).

According to Vachard et al. (2004), this microstructure of tiny alveolae served to house symbiotic algae or cyanobacteria in some fusulinids. It is common in many lituolid genera but incompatible with radial partitions or hypodermic network. This may be due to an incompatibility between symbiotic inhabitants, filamentous bacterial versus larger dinoflagellates. The size of these diverse chamberlets may be related to, and is consistent with, the size of photosynthetic symbionts (20-250 $\mu$ for microalgae).

Some genera develop coarser cylindrical alveolae within the wall (covered by a fragile tectum $(6 \mu)$ ) which can be removed by mechanical abrasion in some mesoendothyrids, erroneously attributed to a "perforate" (an artifact) family "Lituoliporidae" by Gusic and Velic (1978). Transitional microstructures between pseudokeriotheca and alveolae in the wall do exist from the Triassic (Rigaud et al. 2014) to the Jurassic, and the Cretaceous onward (Wernlina, Paleomayncina, Everticyclammina, etc.) (Plate 8.1 (7-10)).

2. The mode of coiling is of prime importance in the definition and separation of Mesozoic clades of ILF and probably of polyphyletic origin (Septfontaine et al. 1991; BouDagher 2008; Mikhalevitch 2013; Kaminsky 2014; see Tables 8.1, $8.2,8.3,8.4$, and 8.5 for details). Two main classical morphotypes or lineages are recognized from the Early Liassic to the Late Cretaceous:

(a) The planispiral to uniserial (discoid) type or mesoendothyrids and hauraniids (Tables 8.2 and 8.3)

(b) The trochospiral to uniserial (cylindrical-conical) type or valvulinids and pfenderinids/kurnubiids (Tables 8.4 and 8.5)

3. The hypodermic network and the vertical radial partitions (see below) are Jurassic innovations dividing the margin of the chambers, already present in the Late Sinemurian. They are shared by different clades and probably diverge in form and size during the Mesozoic depending on the type (and size) of hosted symbionts. The hypodermic network can be irregular, with wavy subvertical and subhorizontal/oblique lamella (Bassoullet et al. 1976). The subvertical (with trapezoidal contour) lamella are detached from the floor of the chambers and attached to the roof ("stalactitic microstructure" in the genus Alzonella, etc.) by its subtriangular base (in vertical section) near the center of the chambers (Plate 8.1 (11-15)). The network can be more regular in some Late Jurassic-Cretaceous taxa like Choffatella, a deeper water genus. 
4. The vertical radial partitions (a Late Sinemurian novelty) are attached to the external wall, contrary to the subdivisions of some Pfenderinids like Satorina issued from the central mass, not reaching the exterior wall. They divide the marginal zone of the chambers into chamberlets as in recent porcelaneous discoid equivalents. Horizontal subdivisions are absent in both cases (Plate 8.1 (16-20)). The partitions are plain or trapezoidal in shape or contour. The thickness at the base increases gradually toward the center of the chambers, so that the partitions show a characteristic triangular shape in vertical sections, with a "bifid" appearance in basal section. Near the central zone, the partition system generally does not coalesce at the base with the central infill, defining an "annular free zone" connected with the "crosswise oblique stolon system" sensu (Hottinger 1967). This later architectural arrangement is a Bathonian innovation appearing firstly with the genus Meyendorffina and later in the Early Cretaceous Orbitolinids (by homology) and Eclusia (Plate 8.1 (19-20)) described in Septfontaine (1971), Cherchi and Schroeder (1975).

5. The pillars (cylindrical or half-conical) are directly linked to the multiple apertures in the center of the chambers arranged in different stolon systems as in valvulinids and orbitolinids. The pillars are triangular in vertical sections and can be confused with the triangular sections of the radial partitions near the central zone of the chambers close to the central calcitic filling of some genera like Meyendorffina.

6. The apertures are associated with the central stolon system, straight or crosswise-oblique (Hottinger 1967) in discoid morphotypes, in relation to the dynamic protoplasm flux. Trochospiral valvulinids and pfenderinids show single (interiomarginal) or multiple apertures (pores) covered by a septal flap sometimes "trematophore-like," and modified in the pfenderinids in a central vertical halftube (half columella) or "tooth plate" sensu Hofker in Hottinger (1967). The associated characteristic triangular-vertical partitions defining the EclusiaIlerdorbis morphotype appear later during Bathonian times in valvulinids and pfenderinids like Meyendorffina; see Tables 8.4 and 8.5.

\subsubsection{Discussion}

It is possible to draw some general trends concerning the relation between coiling and some internal microstructures as follows:

- The planispiral mesoendothyrids and trochospiral valvulinids/pfenderinids ${ }^{2}$ are devoid of any subdivision in the marginal zone of the chambers. Instead, a pseudokeriotheca is always present in the (thick) wall covered by a tectum; pillars can

\footnotetext{
${ }^{2}$ The special case of the valvulinids Pseudodictyopsella-Dictyopsella and the "Kurnubiids" with a hypodermic network (without pseudokeriotheca) is discussed in Tables 8.4 and 8.5.
} 


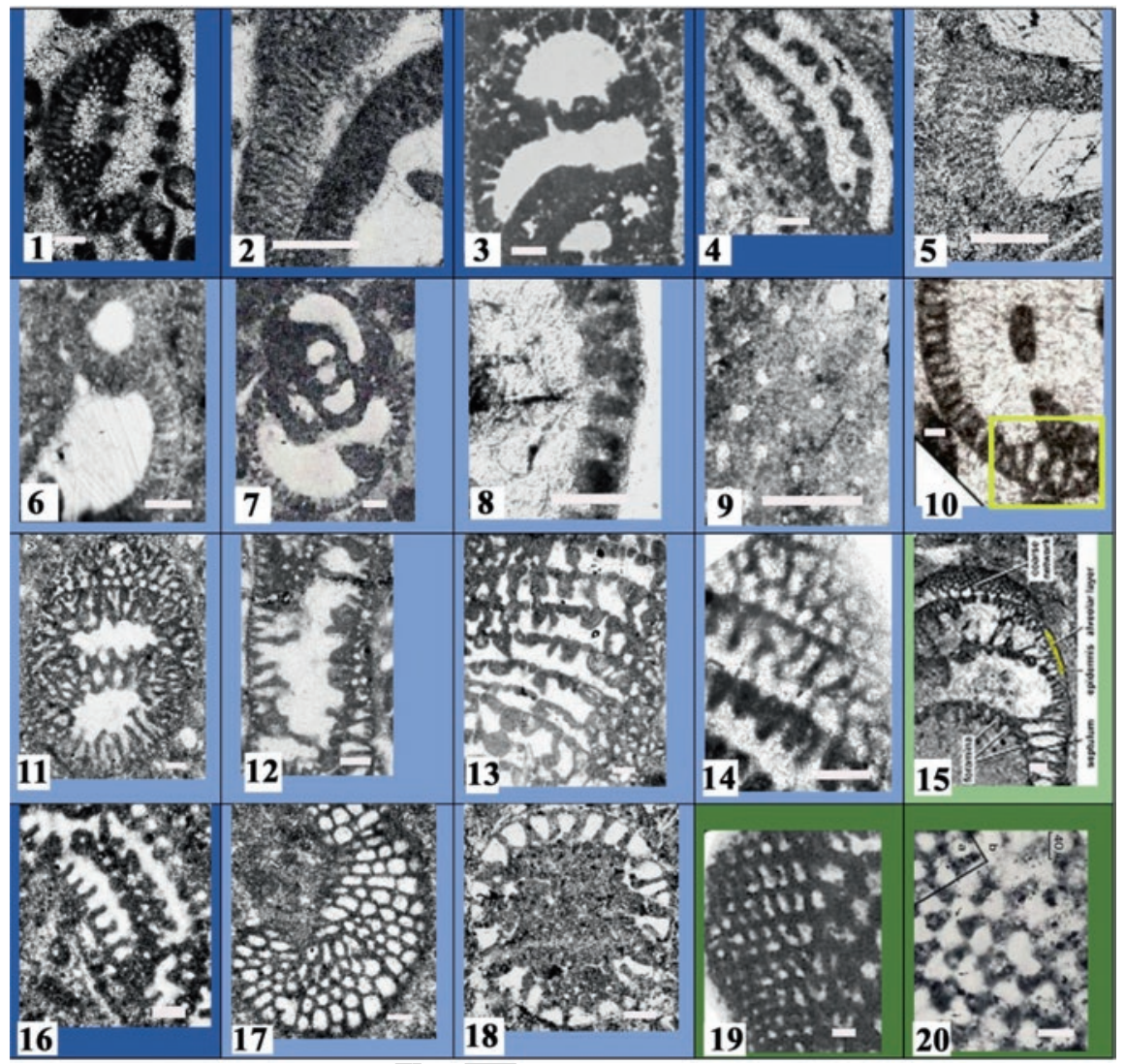

Plate 8.1 Wall microstructures: pseudokeriotheca and alveolae (1-10) with transitions (diam. $5-15 \mu)$ and divisions developed in the marginal zone of the chambers: hypodermic network (11-15) (length 40-200 $\mu$ ) or radial vertical partitions (16-20) (length $100 \mu$, without transitions). The walls (3) (Paleomayncina in Loeblich and Tappan 1988) and (10) (Dubrovnikella in Schlagintweit and Velic 2011, thickness $70 \mu$ ) show clearly the transition, respectively, between pseudokeriotheca and alveolae and alveolae to the hypodermic network (in Dubrovnikella, yellow rectangle)

Colors: dark blue $=$ Middle Liassic; middle blue $=$ Dogger; dark green $=$ Early Cretaceous; light green $=$ Late Cretaceous

The sizes (diam.) of alveolae and chamberlets vary from 5 to $20 \mu$ (pseudokeriotheca-alveolae) to $40 \mu$ or more (hypodermic network-radial partitions). This variation is possibly related to the size (or number) of symbionts, e.g., bacterial filaments (Vachard et al. 2004), dinoflagellates, or other algae, in a perspective of coevolution

List of genera (scale white bar ca $50 \mu$ ):

1 Paleomayncina (pseudokeriotheca and multiple openings)

2 Biokovina (pseudokeriotheca, excerpt from Gusic (1977))

3 Paleomayncina (transition pseudokeriotheca-alveolae, excerpt from Loeblich and Tappan (1988))

4 Paleomayncina (advanced flabelliform to reniform type)

5 Chablaisia (pseudokeriotheca)

6 Paleopfenderina (pseudokeriotheca) 
7 Mesoendothyra (transition pseudokeriotheca-alveolae)

8 Everticyclammina (alveolae)

9 Everticyclammina (detail of alveolae)

10 Dubrovnikella (transition alveolae to laminae of the hypodermic network (yellow frame), excerpt from Schlagintweit and Velic 2011))

11 Pseudocyclammina (hypodermic network, long vertical laminae below)

12 Alzonella (hypodermic network with long irregular vertical laminae as Persiacyclammina (15))

13 Alzonella (idem, peloids form irregular vertical laminae)

14 Anchispirocyclina (hypodermic network, irregular laminae)

15 Persiacyclammina (fine hypodermic network with important development of main vertical lamellae toward the center of the chambers as in Alzonella (12)—excerpt from Schlagintweit and Rashidi 2017a)

16 Orbitopsella (vertical regular radial partitions, left)

17 Meyendorffina (vertical regular radial partitions, tangential/axial section)

18 Meyendorffina (vertical radial partitions becoming triangular in section near the central calcitic filling; basal section)

19 Orbitolinid (hypodermic network (left) and triangular main vertical partitions or lamellae, right)

20 Eclusia (triangular sections of radial partitions near the center of the chambers in a "crosswise oblique" stolons or "marginoporiform" system) (Hottinger and Caus 1982)

be present in the central zone of the chambers, associated with the cribrate openings and the dynamic protoplasm.

- Conversely, the planispiral-to-discoidal hauraniids and biserial dicyclinids never develop a pseudokeriotheca, but instead develop variable marginal microstructures (hypodermic network or radial partitions, see above) associated to the tectum.

- Central calcitic filling (plus pillars) with secondary ways formed by resorption/ dissolution (tunnel, groove, spiral canal, or solid columella) develops only in trochospiral tests.

The hypodermic network and vertical radial partitions are specific Jurassic constructions unknown during Paleozoic and Triassic times. These two basically different architectures are both built from the exterior wall (exoskeleton auct.), and probably of polyphyletic origin during Early Liassic times, without morphological transitions between both. However, vertical regular "lamellae" of the hypodermic network (Plate 8.1 (19)) of orbitolinids can be assimilated morphologically to vertical radial partitions of other Jurassic taxa. It must be noted that the regular hypodermic network of orbitolinids is not known in the Jurassic, and can be interpreted as a novelty appearing during Early Cretaceous times.

These microstructures (Plate 8.1) appear iteratively through time in different clades distinguished by their mode of coiling (Tables 8.1, 8.2, 8.3, 8.4, and 8.5), and are considered of secondary importance in taxonomy. Nevertheless, an alternative proposition can be envisaged and the reverse (wall and marginal microstructures first, and coiling as a secondary character) can also be a relevant solution but not retained here. Likewise, the pillars and other structures associated with the cribrate aperture can be considered as secondary (but advanced) characters appearing as isomorphic (analogous) traits in different clades during their evolution. 
t1.1 Table 8.1 General test shapes and innovations of imperforate larger foraminifera

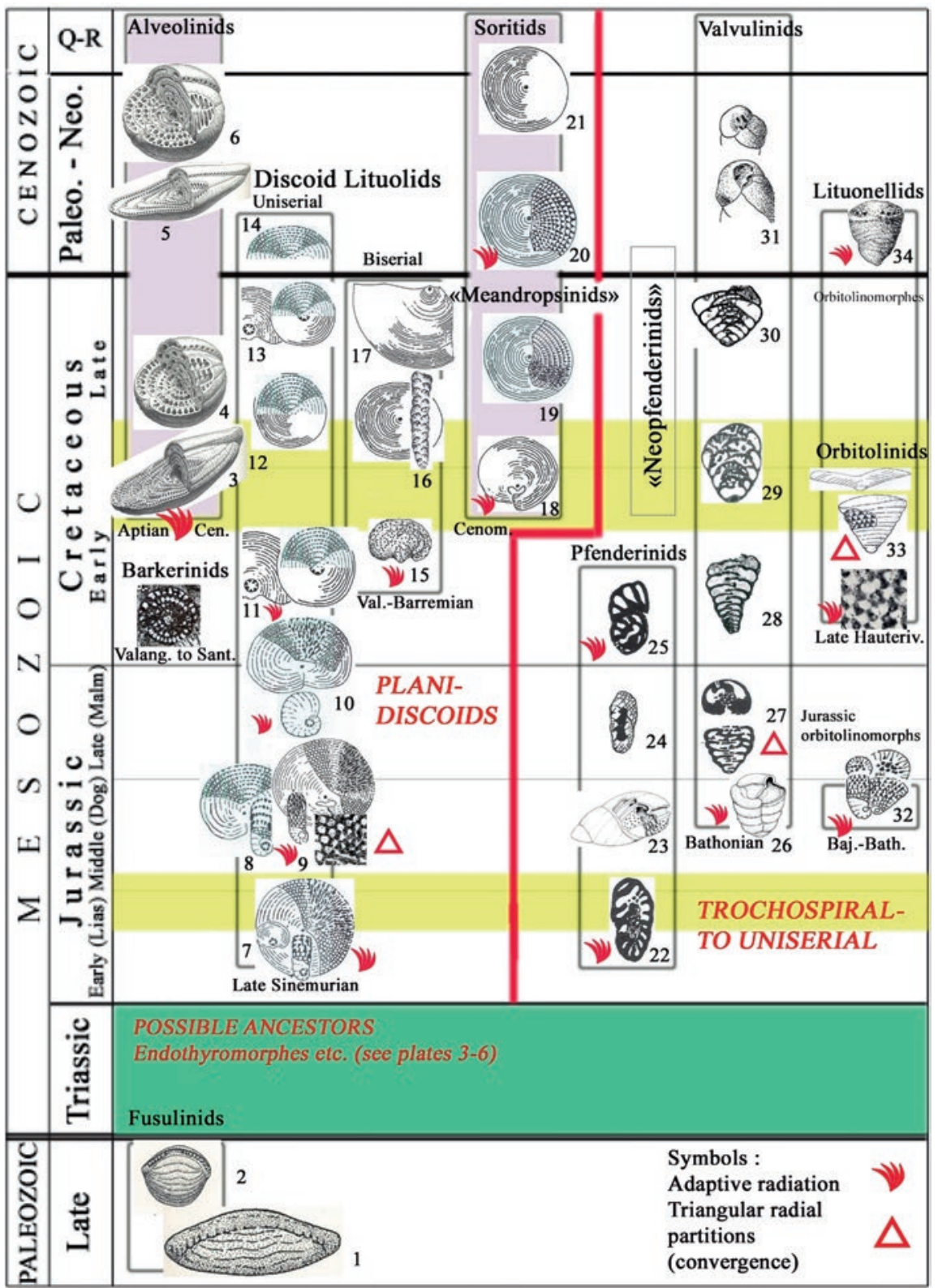

t1.2 Morphological novelties and iterative evolution among ILF (and microgranular isomorphic t1.3 porcelaneous alveolinids and soritids, in light grey) during Phanerozoic times. General coiling t1.4 and shape planispiral-discoid (7-21) or fusiform-globular (1-2; 3-6; and Barkerinids) left of t1.5 the red line versus elongate-trochospiral coiling of the test on the right. Note the first original 
Table 8.1 (continued)

appearance (7 and 22) of planispiral-discoid tests on the one hand, and trochospiral (pfenderinids) morphotypes on the other (in the Late Sinemurian) after the main OAE crisis of the Late Triassic. Some innovations of microstructures (hosting symbionts) in the marginal zone of the chambers are characteristic of the Mesozoic (hypodermic network; radial partitions with triangular axial section, see Plate 8.1), while others like the pseudokeriothecal wall represent a Paleozoic heritage. These microstructures are distributed iteratively in variable major clades: (1) strepto to planispiral or (2) trochospiral to uniserial/biserial. Note that the biseriality in discoid ILF foraminifera (1517) is an Early Cretaceous novelty as well as the appearance of globular tests in Barkerinids Yellow bands are periods of successive anoxic crisis (volcanism), e.g., OAE in the ToarcianAalenian and in the mid-Cretaceous (Albian-Cenomanian-Turonian, OAE 1b-2). For detail of anoxic periods see the caption of Table 8.2. Green band emphasizes the Triassic period with its specific microfauna (involutinids, endothyrids, see Plate 8.3, and a general dwarf microgranular microfauna). Aragonitic wall of involutinids (not shown) persists during the Mesozoic

Note that later anoxic periods during the Mesozoic have no major influence on appearance or demise of main morphotypes and microstructures, which are more related to coevolutive genetical processes between the host cell and probable symbiotic bacteria or algae

Fusulinid icons from Cushman (1933); alveolinid icons from Reichel in Loeblich and Tappan (1964)

(1) Triticites (icon excerpt from Cushman 1933); (2) Schwagerina (excerpt from Cusman 1933); (3) Praealveolina; (4) Ovalveolina; (5, 6) Borelis; (7) Orbitopsella (icon excerpt from Septfontaine 1988); (8) Alzonella; (9) Meyendorffina-Orbitammina; (10) Timidonella; (11) Balkhania; (12) Pseudochoffatella; (13) Neobalkhania; (14) Vania; (15) Cuneolina; (16) Dicyclina; (17) Suraqalatia (Giant Dicyclinid, diam. $7 \mathrm{~cm}$ ); (18) Pastrikella (Broeckina); (19) Meandropsina (redrawn from Loeblich and Tappan 1964); (20) Orbitolites; (21) Sorites-AmphisorusMarginopora; (22) Pseudopfenderina; (23) Paleopfenderina; (24) Kurnubia; (25) Pfenderina; (26) "Praevalvulina" = Valvulina (Redmondoides); (27) Parurgonina; (28) Praechrysalidina; (29) Chrysalidina; (30) Accordiella; (31) Valvulina; (32) Gutnicella; (33) Cribellopsis-Eclusia and Orbitolina; (34) Lituonella

However, the estimation of the hierarchical weight of characters is most often a subjective construction in a pure cladistic approach. An "a priori" decision can be refuted by further studies and new data. Then by experience within a particular group, it is questionable to classify morphological characters into specific, generic, or even higher taxonomic categories, as morphological elements (traits) do not have intrinsic significance or weight, as discussed by Fleury (2018) for larger miliolids. A character susceptible to distinguishing between species could be found again, but at a generic level and conversely a character permitting to distinguish genera will be found in the separation of diverse species. It may be the case for some lituolids, e.g., the test shape and contour of pfenderinids/Nezzazatinella or Planisepta and others discussed in Tables 8.2, 8.3, 8.4, and 8.5. Such complexity is due to the fact that the diverse morphological traits evolve independently, the ones from the others and at a different speed ("mosaic evolution," see Dollo in Gould 1977). Associations of characters should be considered to identify the evolutionary trends in their complexity and to distinguish them in a more general perspective (through space and time). This method needs a good global understanding of the considered group of foraminifera and the results must be shaded (or completed) with the addition of stratigraphical and paleoecological data. 
t2.1 Table 8.2 Polyphyletic planispiral morphogroups of flabelliform-reniform to discoid adult-shape t2.2 larger foraminifera, uniserial (A to E) or biserial (F) with (or without) various "exoskeletal"

t2.3 marginal microstructures hosting endosymbionts, with (or without) central pillar "endoskeleton"

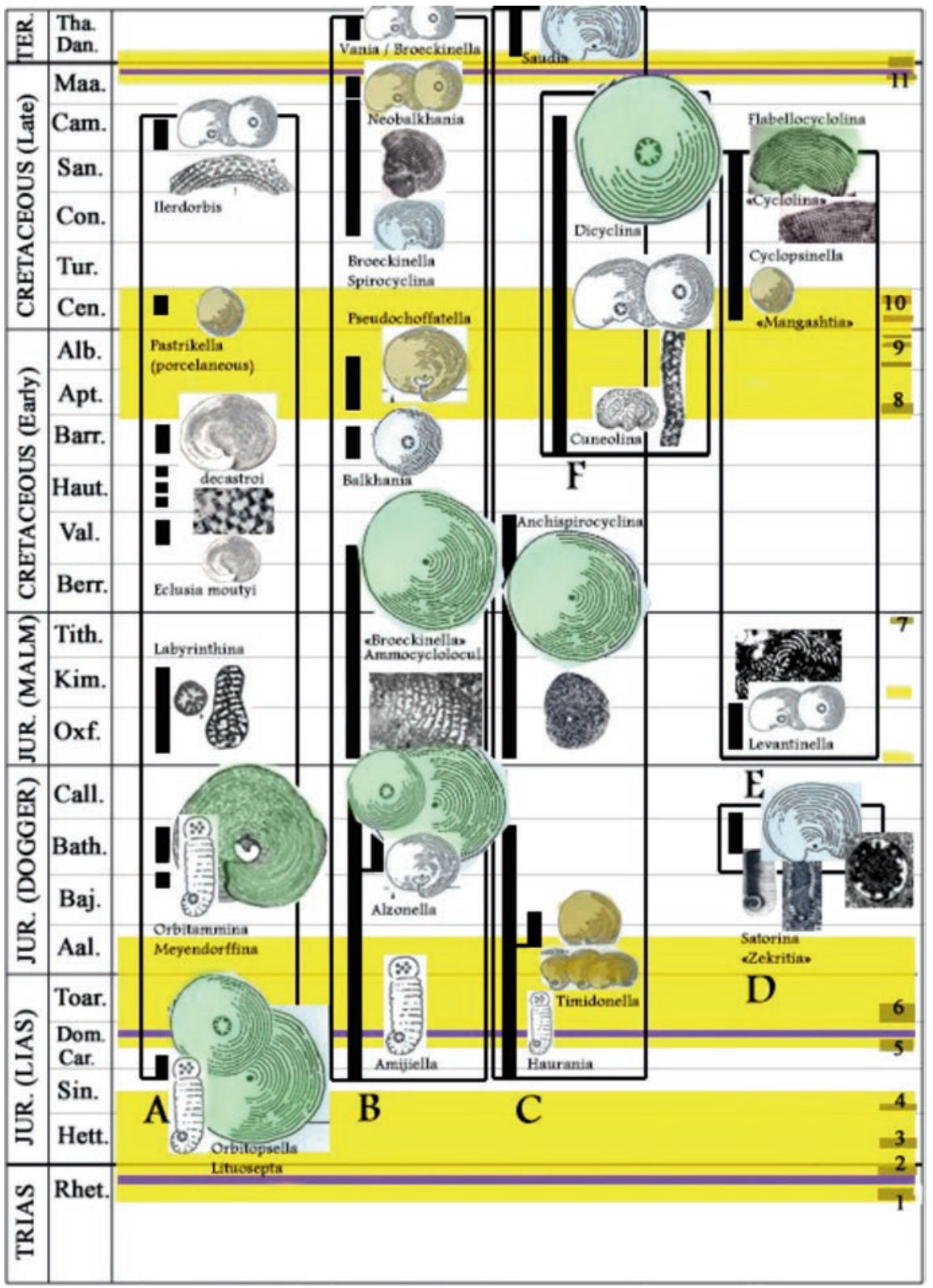

(continued) 
Table 8.2 (continued)

\section{Aperture multiple, cribrate, or pores aligned}

Left to right: (A) with marginal radial partitions (orbitopsellids) becoming triangular in section near the center (Meyendorffina, Eclusia-Ilerdorbis) and pillars. (B) With a marginal hypodermic network, without pillars in the central zone of the chambers, aperture cribrate (amijiellids s. str.), or in one row (Broeckinella, etc.). (C) With marginal hypodermic network and cylindrical pillars in the central zone of the chambers (hauraniids). (D) Without marginal partitions s. str., but with radial divisions extending from the center calcitic infill to the margin of the chambers (not joining the tectum) as in Satorina. (E) Without marginal partitions but with central pillars (Levantinella, "Manghastia," Cyclopsinella). (F) Biserial test with marginal hypodermic network (cuneolinids). Biseriality is an important Cretaceous innovation among reniform-discoid larger foraminifera, as Cuneolina an Early Cretaceous ancestor of Dicyclina and Suraqalatia (giant test, diam. $7 \mathrm{~cm}$, not shown)

- Yellow surfaces: periods of warming with anoxic conditions, a long period of stress for larger discoid foraminifera with a record of small-size individuals (2-3 mm diam.) and general low biodiversity (icons colored in brown)

- White surfaces: periods of "normal" conditions, medium size (11-13 mm diam.) to very large "monstrous" tests (20-70 mm diam. in dicyclinids), indicating stable and comfortable conditions for vegetative symbiotic life (K-strategist), but fragile and doomed to extinction in a changing environment (Hallock 1985). Icons colored in light green

Note: the small to medium diameters of discoid tests are roughly at scale. The true ratio between very large tests (green) to small tests (brown) is 20:2, not on the scale in Table 8.2

In Tables 8.2, 8.3, 8.4, and 8.5, numbers 1-11 (brown) refer to main peaks of anoxia (OAE), warming and cooling (blue) events during the Mesozoic (detailed below). For impact on larger foraminifera populations, see also the review of BouDagher (2008)

1. Late Rhaetian, Guex (2016)

2. Triassic-Jurassic boundary, $-201 \mathrm{Ma}$. CAMP Atlantic magmatism and sea-level fall. Hallam and Wignall (1999), etc.

3. Hettangian planorbis/pacificum warming event (Guex 2016)

4. Early Sinemurian semicostatum warming event

5. Late Pliensbachian (Domerian) margaritatus warming and cooling (in blue) events

6. Late Pliensbachian and Early Toarcian falciferum/exaratum period and peak of warming (in brown), worldwide T-OAE (-183 Ma). Jenkins (1988), review in Rosales et al. (2018) and Duarte et al. (2019). South Africa Karoo Traps, magmatism

7. Late Tithonian warming event, Oxfordian "black shales," and Kimmeridgian "Orbagnoux bituminous shales" (yellowish brown) are not numbered and considered as local restricted anoxic deposits, like the eutrophic Bathonian-Callovian "Mytilus beds" in the Briançonnais realm (black muddy inner platform deposits) rich in imperforate trochospiral larger foraminifera, but without discoid larger morphotypes

8. Early Aptian worldwide anoxic event; OAE 1a or Selli event, Ontong-Java 1. Demise of the Urgonian platform (Föllmi 2008). Barents sea High Arctic magmatism (HALIP)

9. Albian anoxic events (Mid-Cretaceous events). OAE 1b-d (Strasser et al. 2001)

10. Mid- and Late Cenomanian anoxic and drowning events (Mid-Cretaceous events). Late Cenomanian anoxic event OAE 2

11. Maastrichtian warming and cooling events. Deccan Traps, bolide impact on Yucatan and massive extinction. Shallow water larger imperforate discoid foraminifera paradoxically not strongly affected. "Lazarus" effect (Wignall and Benton 2000) or recovery in Paleocene-Eocene times 
t3.1 Table 8.3 The mesoendothyrids (Mesoendothyridae emend., left and center columns of this

t3.2 table) include morphogenera representing a Paleozoic heritage, through Triassic forms, of rather

t3.3

t3.4 stable morphotypes (coiling strepto-irregular to planispiral) with pseudokeriothecal-to-alveolar structure (symbionts bearing in advanced forms) with a thick wall

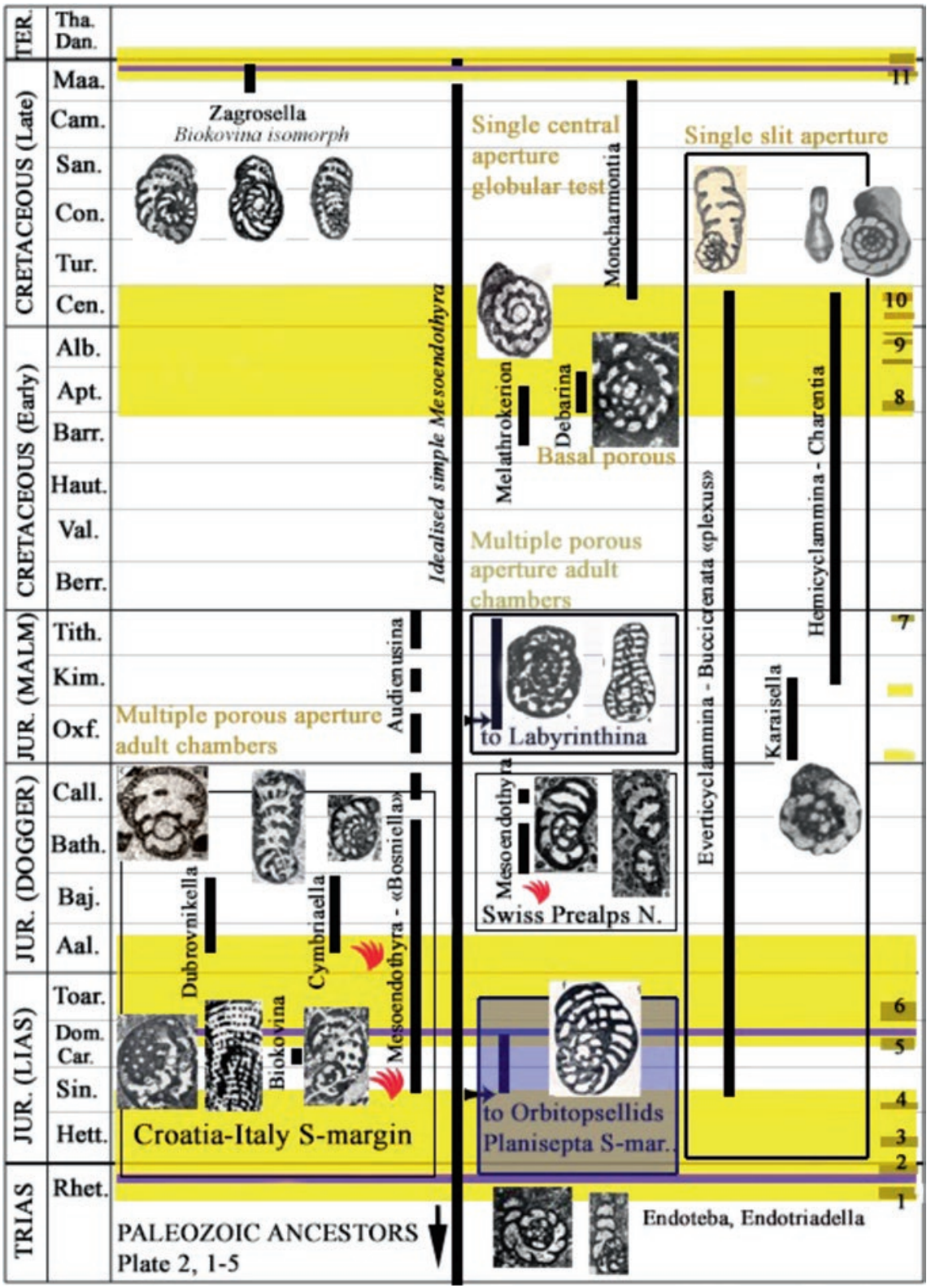


Table 8.3 (continued)

The septa display a conspicuous "spinose, rose thorn" contour, and are tangential to the previous whorl in an equatorial section (see Plate 8.3). The simple basal-to-central opening in early chambers becomes multiple in the adult. The mesoendothyrids cross severe anoxic environmental crises (1-11 in brown, yellow band) without being affected, after the main P/T extinction. But some Mesozoic innovations are not known before the Middle Liassic, like multiple porous openings and pillars in the adult stage as recorded in Middle Liassic-to-Dogger and later Maastrichtian levels, following an iterative (somewhat "chaotic") mode of appearance from a simple stock of the Mesoendothyra "plexus"

The everticyclamminids (right column) with a single-slit aperture (straight or sinuous) were probably issued from a mesoendothyrid ancestor during Early Liassic times. The classic alveolar microstructure of the wall (a Triassic and Liassic innovation) is interpreted as a coarse pseudokeriotheca hosting a particular type of larger symbiont (unknown dinoflagellates)

The characters $\mathbf{a}-\mathbf{f}$ defined above are presented in hierarchical order as elements of the classification used in the present study and correspond roughly to the generally accepted classification of lituolids on carbonate platforms by recent authors (Mikhalevitch 2013; Kaminsky 2014).

\subsubsection{Defining a Stock of Simple Atavic Persistent Morphotypes}

After the main periods of foraminiferal extinctions affecting benthic and planktonic populations during the Mesozoic, the apparition of rare, smaller, morphologically simpler taxa, from which new clades could evolve, has been classically observed by various authors (e.g. Arriaga et al. 2016). These atavic forms (survivors) were partly identified in the Early Jurassic (with a problematic taxonomic status) and briefly discussed by Septfontaine (1984b, 1988) and some siphovalvulinid species introduced by BouDagher and Bosence (2007). They are considered as good candidates at the origin of the different morphogroups considered below (Tables 8.2, 8.3, 8.4, and 8.5) with a very long stratigraphic extension through the Mesozoic and the Tertiary. To be cited are smaller endothyrid-like (Mesoendothyra), smaller and rare "praevalvulinids*”, abundant siphovalvulinids (Siphovalvulina), etc., all persistent atavic morphotypes representing a genetical plexus or "reservoir" from which successive advanced homeomorphic genera diverge iteratively. The origin of hauraniids is more problematic. Globally the model of "retrograde evolution" proposed by Guex (2016) for the planktonic rotaliporiids during anoxic Middle Cretaceous extinction crises was not observed among Mesozoic larger benthic foraminifera (see also Arriaga et al. (2016) for the end-Cenomanian crisis), due probably to their particular complexity and intolerance to environmental changes as already stated. 
t4.1 Table 8.4 Mesozoic valvulinids ("praevalvulinids*” and chrysalidinids) display trochospiral t4.2 morphotypes with three or more chambers per whorl, a pseudokeriothecal wall (in advanced larger t4.3 forms), and a valvular "tooth plate" simple or modified in the central umbilical zone, with conical t4.4 pillars associated to pores of a cribrate aperture through the tooth plate (advanced forms)

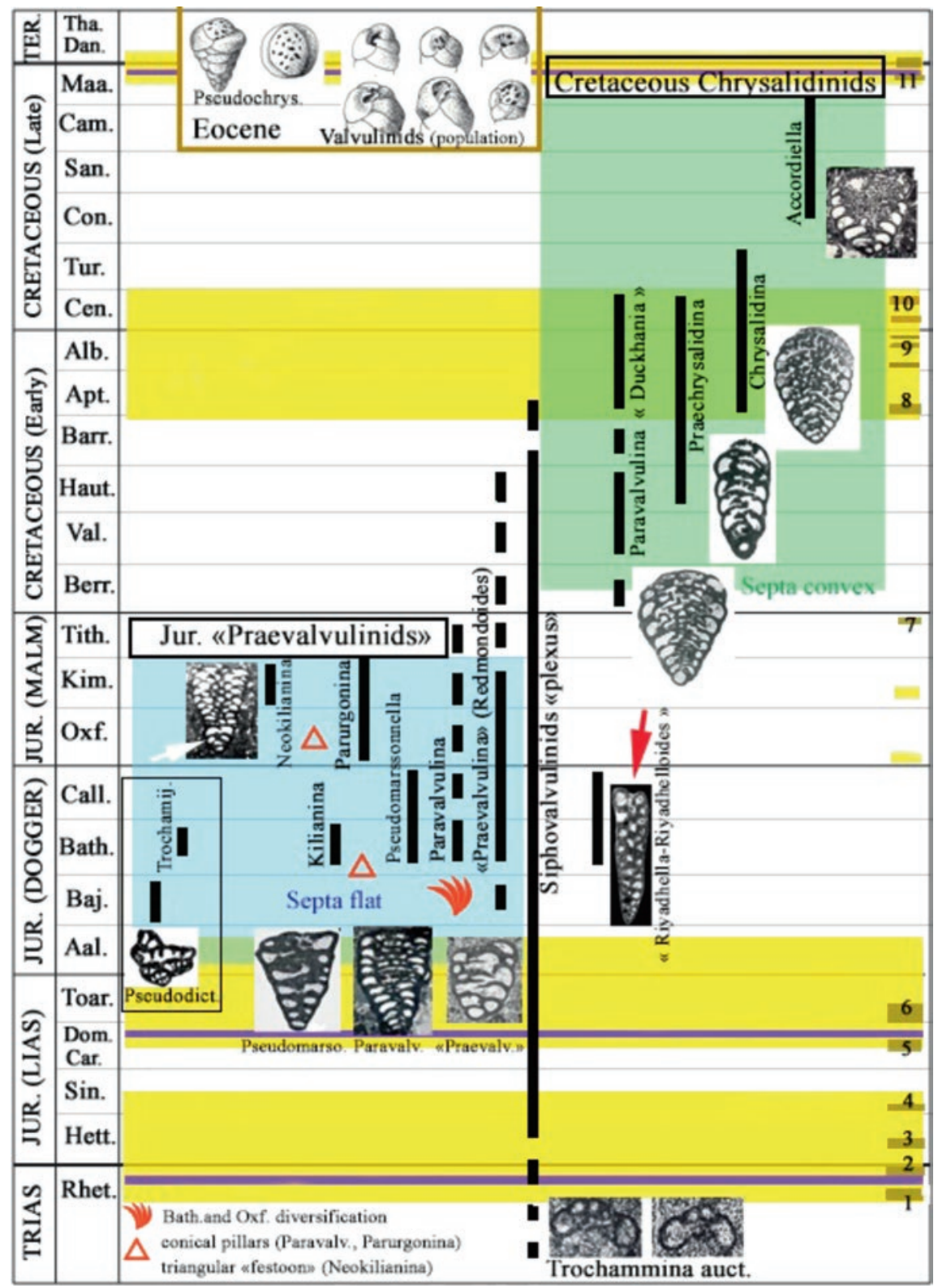

(continued) 
Table 8.4 (continued)

The morphotypes include (left of the central siphovalvulinid "plexus" on plate) (1) the Jurassic praevalvulinids* (septa flat) and to the right and (2) the Cretaceous chrysalidinids (septa convex) with transitions at the $\mathrm{J} / \mathrm{K}$ limit. The siphovalvulinid "plexus" is composed of ancestral simple forms with a central siphon or hollow columella supposed to produce a poorly developed "tooth plate" (after deformation of the columella wall) omnipresent through the Mesozoic (representing a constant "genetic reservoir") from which several complex descends (see also Plate 8.5, pfenderinids) are issued following an iterative mode till the Tertiary (Eocene to recent). Red arrow: siphon in the last chambers of "Riyadhella-oïdes" morphotype. White arrow: early praevalvulinid* ontogenetic stage in Neokilianina

Note apertural (local ecophenotypic) variations of the "tooth plate" in an Eocene synchronous population (top of the plate, from Neumann 1967) as commonly observed in some Jurassic stocks of "praevalvulinids*"

\subsection{Impact Appraisal of External Abiotic Factors on Iterative Phyletic Morphogenesis and Individual Morphological Trends}

\subsubsection{General}

The relations between main abiotic events and marine invertebrate population turnovers or extinctions are still unclear (e.g., for the K/T extinction, Mac Leod et al. 1997; Abramovich et al. 1998; Archibald et al. 2010 for Globotruncanids) at a global scale, and the impact of smaller cyclic environmental changes on a morphogenetical trend in a single bioseries (e.g., the orbitopsellid model Fig. 1 discussed by Septfontaine 1984b) seems insignificant. Extensive studies on the subject at a larger scale conclude variable importance of environmental factors (Font et al. 2016) during the major crises on mode, tempo, and synchronism of extinctions, mainly volcanism and main peaks of anoxia (1-11, Tables 8.2, 8.3, 8.4, and 8.5). For example changes in biotic assemblages indicate a marine ecosystem crisis prior to the oxygen depletion for P/T anoxia in Norway (Dustira et al. 2013). However, Burger (2019) links the major P/T extinction with massive combustion of coal responsible for global warming and ocean acidification during Siberian Traps volcanism. For other authors, the onset of eruptions slightly post-dates the main phase of faunal disorders during several extinction periods (e.g., Wignall 2001), and the link between LIP's and extinctions remains enigmatic. The Early Jurassic extinction event (Late Pliensbachian-Toarcian OAE) was not synchronous throughout the Tethyan region (Wignall et al. 2006; Metodiev et al. 2012), and this Jurassic extinction may have been a regional crisis rather than a more severe global catastrophe (Wignall and Racki 2006). More precisely equating the timing of LIP eruptions to extinctions is generally difficult (Van de Schrootbrugge and Wignall 2016). The Deccan volcanism is dismissed as much older than the K/T extinction which is considered as a multicausal (warming and cooling, etc.) long-term scenario and not a single one (Keller et al. 2010; Punekar et al. 2015). On the other hand, many faunal turnovers or extinctions, including benthic (larger) foraminifera, began already in 
t5.1 Table 8.5 Repartition of trochospiral pfenderinid morphotypes and associated forms in the

t5.2 Mesozoic, with morphological innovations (Italic)

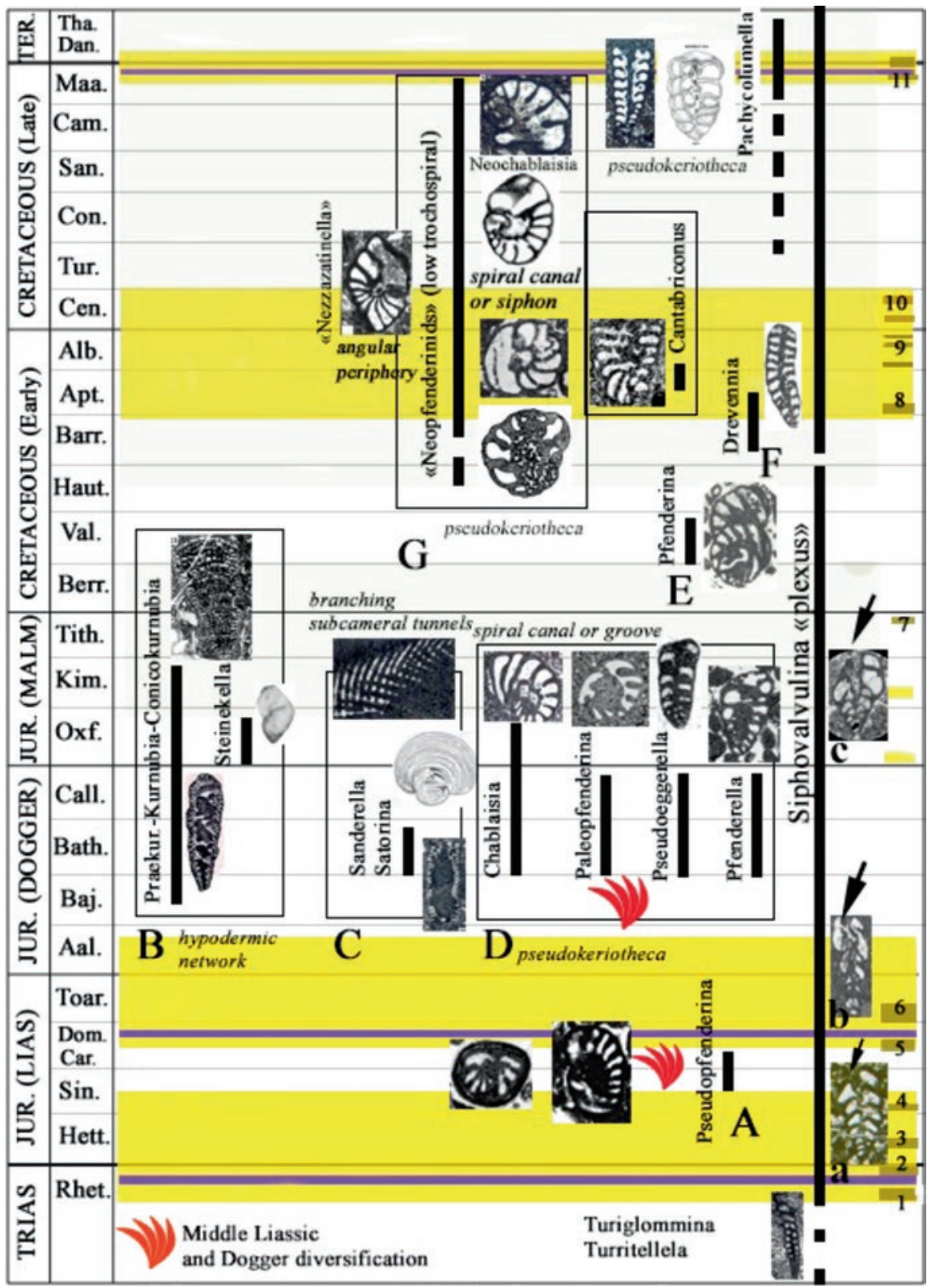

t5.3 The first appearance of the group, characterized by a central columella (filled central siphon, arrows

t5.4 a, b, c extreme right of the table) and calcitic infill between pillars with later resorption (groove,

t5.5 canal), is in the Middle Liassic (A), after a period of climatic changes (warming and cooling) from 
Table 8.5 (continued)

t5.6

t5.7

$\mathrm{t} 5.8$

t5.9

t5.10

t5.11

t5.12

t5.13

t5.14

t5.15

t5.16

t5.17

t5.18

t5.19

the Late Triassic to the Early Sinemurian (1-4). A second diversification period (B-D) is in the Late Bajocian-Bathonian to Callovian interval, as for the valvulinids, after the Toarcian anoxic event (6), continuing in the Early Dogger. Advanced forms show an uncoiled "orbitoliniform" cylindrical-toconical adult stage (B) as Conicopfenderina (not shown, see Plates 5-25) or Conicokurnubia. The genus Satorina shows an exceptional development of arched adult chambers with multiple subcameral tunnels (C). The pfenderinids s. str. are absent from the Kimmeridgian-Tithonian interval, characterized by the kurnubiids and advanced Conicokurnubia with a hypodermic network (B), probably issued from a Siphovalvulina stock. A new apparition of the pfenderinids s. str., without a direct link with Jurassic morphotypes, occurs in the Valanginian with the well-known Pfenderina neocomiensis (E) of large size, issued probably from the ancestral stock, like the younger variant Drevennia $(\mathrm{F})$. Other Cretaceous morphotypes with a low trochospire and a spiral canal or an open umbilicus (sometimes filled by pillars) are considered as modifications of the Siphovalvulina plexus with simpler morphology. The genus Pachycolumella is a Maastrichtian-Paleocene newcomer, homeomorph of Radoicicina (Liassic, not shown) with a Siphovalvulina-like morphology

the latest Maastrichtian (Mac Leod et al. 1997), and many other faunal taxa, including benthic foraminifera (Table 8.4 and 8.5), survived the K/T crises with minor diversity changes. The Newell's regression hypothesis is tenable for the end Triassic extinction but not for other crises; Globotruncanid demise within the Maastrichtian in several steps occurs far below the K/T crisis (Hallam and Wignall 1999). One of the largest continental flood basalts in the Toarcian is associated with only a minor crisis, so then why do some LIP's trigger major extinction events while others do not? (Bond and Wignall 2014). In Morocco, the Liassic microfaunal turnover occurs earlier than the Toarcian, during the Domerian (margaritatus zone, Table 8.6). A more general review with references for abiotic events affecting the biosphere is presented by Font et al. (2016).

\subsubsection{Possible Influence of Environmental Changes and Major Events on Morphogenesis}

In normal conditions, between main anoxic events (OAE, 1-11 on Tables 8.2, 8.3, 8.4, and 8.5), members of some ancient species become very large (a tenth of a centimeter in extreme cases) and complex compared with modern forms, and follow roughly the schematic trend displayed in Fig. 8.2. This could be an indication that Mesozoic carbonate platforms, their size and paleogeography, represent more stable and oligotrophic conditions in low latitude than in modern oceans (Hallock 1985). In these oligotrophic conditions larger symbiotic bearing foraminifera (K-strategists) will be favored, but paradoxically at the same time, their high specialization (resulting from coevolution) dooms them to extinction. Indeed larger foraminifera are very sensitive to abrupt changes of environments like sea-level variations and general drowning of the platforms; vast areas of warm shallow seas were isolated from any input of nutrients from land or the deep sea (Hallock 1982, 1985). Then massive extinctions are triggered by environmental changes that are too rapid for many spe- 
cies to respond either by migration or by physiological (morphological) adaptation (Herman 1981; Hallock 1985) but, on the other hand, foraminiferal associations (as the orbitopsellids ${ }^{3}$ ) support gradual and local environmental changes as recorded in metric parasequences (point $\mathrm{C}$ discussed below; Table 8.6).

Evolutionary diversification (adaptive radiation) occurs in rather constant conditions on carbonate platforms through time. Major diversification (and innovations) of larger foraminifera (at a generic level) occurs at different periods, starting with the Early Liassic, after the Triassic extinction, later during Middle and Late Jurassic times after the Late Liassic anoxic crisis (Septfontaine et al. 1991, Table 8.6) and during the Early and Middle Cretaceous at a higher taxonomic rank (Ross 1974; BouDagher 2008) with some innovations (Table 8.1). But strangely enough, several Mesozoic isomorphic morphotypes of hauraniids, valvulinids, and pfenderinids (discussed below) cross the K/T crisis and are represented in the Early Tertiary. The general repartition through time of main morphotypes (genera) of microgranular larger foraminifera of the Mesozoic is resumed in Tables 8.1, 8.2, 8.3, 8.4, and 8.5 and clearly illustrates an iterative mode of evolution as already discussed by Septfontaine (1981, Septfontaine 1988).

\section{General Shape and Coiling (Table 8.1)}

The shape of the test reflects adaptation to different types of environments characterized chiefly by water energy, attachment or free living, sediment granulometry (Hohenegger 1994 for porcelaneous recent equivalent), and variation on carbonate platforms from coarse reefal sand to muddy lagoonal sediment. The test shape is also an expression of the chamber volume variations (increasing through time in bioseries), probably related to symbiotic coevolution. On the other hand, the episodic (but widespread through time) transportation of tests by currents or hurricanes may locally complicate the interpretation of fossil associations displaced in variable foreign environments onshore (lagoon or tidal flat, Davaud and Septfontaine (1995) in the Recent; Septfontaine (1985) in the Liassic of Morocco; Septfontaine (unpublished) for transportation of floated fusulinid tests in supratidal environments, Permian olistolites, Hawasina nappe, Oman). Then caution must be taken when interpreting morphology related to environmental conditions for fossil groups in an adaptative (epigenetic) perspective.

At a larger scale, global events like anoxic crises (OAE) drive to general extinctions and leave free ancient ecological niches; they play a major role in the replacement of ancient lituolid clades by new ones (population turnovers), as is the case after the T/J, the Late Pliensbachian (Table 8.6), and the Late Cenomanian events (Arriaga et al., 2016). These events give rise in the aftermath to new morphotypes

\footnotetext{
${ }^{3}$ Names of suprageneric taxa are informal (morphogroup termination -ids) considering (1) general shape and mode of coiling (plani-plani/strepto-trochospiral) and (2) type of wall microstructure or marginal architecture hosting symbionts and are, provisionally, considered as different convergent, isomorphic repetitive characters in various clades.
} 
belonging to different clades. Among lituolids, these advanced populations are issued from simple pioneer forms persistent on the carbonate platforms, with planispiral (later discoidal tests) or trochospiral (later cylindrical to conical tests) coiling (Table 8.1). Some specific test shapes like the fusiform-to-globular alveolinids or globular lituolids (Barkerinids, not represented in Table 8.1) are curiously absent from the Triassic (except Triasina) to the Early Cretaceous. Globular Barkerinids are not related to a major climatic crisis period during the Berriasian (Schlagintweit et al. 2019), but rather possibly start from an adaptation to local conditions. The apparition of globular alveolinids in the Aptian (BouDagher 2008) may be linked to environmental changes, as the Aptian begins a period of general anoxia (OAE1a or Selli event) starting during the Mid-Cretaceous OAE 1b-d events. On the contrary, discoid, larger lituolids are omnipresent from the Liassic hereafter, and are a novelty issued from the aftermath $\mathrm{T} / \mathrm{J}$ extinction event. The discoid test shape is persistent till the Early Tertiary, shared by some porcelaneous counterparts appearing in the Middle Cretaceous, and still living in recent shallow waters. Biserial fan shape and discoidal cuneolinids represent a major Early Cretaceous (Barremian) innovation apparently not linked to a global environmental change. Trochospiral cylindricalconical complex lituolids belong also to the new incomers after the T/J crisis colonizing free niches on the carbonate platforms (BouDagher and Bosence 2002, 2007). Following the K/T extinction, several representatives of fan shape to discoidal morphotypes (survivors) are still present in the Paleocene, isomorphs of Mesozoic genera (Table 8.2), as well as trochospiral siphovalvulinids and valvulinids.

Obviously, after the $\mathrm{T} / \mathrm{J}$ extinction events, driving to a new morphogenetic revolution, the morphological changes and innovations of chambers and the test shape of LIF rather reflect the product of local conditions or the action of internal factors linked to physiology (and symbiosis) of the cell. The general trend shape transformations in one bioseries (as shown in Fig. 8.2 for discoid lituolids) are also a good indicator of evolutionary steps and trends (covering roughly one or two stages), with a general tendency to increase the volume of the adult chambers by chambers overlapping together with an increase of the density or number of openings (pores) communicating to the exterior on the apertural face (Hottinger 1967), a general rule among larger discoid LIF, planispiral mesoendothyrids, and trochospiral valvulinids and pfenderinids or porcelaneous genera.

\section{Internal Microstructures in Discoidal Tests (Table 8.2)}

Most planispiral-to-discoid genera grouped artificially in Table 8.2 (morphogroups A-F) follow iteratively the general trend displayed in Fig. 8.2, characterized by an increase of test size together with an increase of the chamber volume by overlapping in the equatorial plane interpreted as an hypermorphosis, with ontogenetic truncation of the early planispiral nepionic stage through time (Brasier 1988). The discoid LIF's are of polyphyletic origin, and the supposed parentage with ancestral planispiral Jurassic mesoendothyrids (for the group A: Orbitopsella-Orbitammina-Labyrinthina) or hauraniids (for groups B-C: Alzonella-Timidonella) seems reasonable. The inter- 
nal architecture of the test (see part 4-1, above) consists essentially of various subdivisions of the marginal zone of the chambers by regular radial vertical partitions (for group A), or irregular vertical and horizontal lamella (for groups B-C-F), including the static protoplasm (Hottinger 1967). The central zone is occupied by pillars and calcitic infills associated with the porous aperture, including the dynamic protoplasm. It is supposed that both types of marginal subdivisions (convergent in independent clades A-F) define cavities containing relatively large symbiotic algae, as their recent porcelaneous counterparts (see Plate 8.1). The absence of a pseudokeriotheca in the wall in both cases could mean a replacement (during the evolution of Early Liassic ancestors mesoendothyrids and hauraniids) of symbiotic bacterial filaments hosted in the pseudokeriothecal wall (Vachard et al. 2004) by larger symbionts (possibly dinoflagellates) in the marginal zone of the chambers only. Conversely, the advanced reniform to discoidal "paleomayncinids" (see Table 8.6) display a pseudokeriothecal-to-alveolar microstructure within the wall, without internal microstructures in the chambers, which confirm the incompatibility between the presence of radial vertical partitions or hypodermic networks on the one hand, and the presence of a pseudokeriotheca or alveolae in the wall of a single individual on the other hand. This fact is also confirmed in trochospiral morphogroups (Tables 8.4 and 8.5).

However, it should be noted that some morphogroups of planispiral-discoid LIF (group E, Table 8.2), together with the phylogenetically non-related genera Levantinella, Cyclolina, Flabellocyclolina, and Cyclopsinella, are devoid of any exoskeletal (marginal) subdivisions, implying that symbionts lived probably free within the cytoplasm. In group D (Satorina), subdivisions of the marginal zone are issued from the center calcitic mass (not from the wall), and the genus could be considered as a pfenderinid (Table 8.5).

The internal structural innovations in the margin or the center of the chambers (like the "crosswise oblique stolon system" at the origin of vertical triangular radial partitions) appear rather randomly within different clades (A-D, F) during periods of relative environmental stability, independently of any perturbations, probably linked to genetic or symbiotic factors (coevolution). Obviously, main abiotic events do not influence the construction of a single morphotype, but rather act as a revealer of the best morphological tenable solution after a major global crisis, creating a major extinction among ILF in a changing environment. It is the case for rare morphotypes of hauraniids like the genera Vania or "Broeckinella" (homeomorphic of the genus Alzonella in the Middle Jurassic (Table 8.2, group B)) which cross the $\mathrm{K} / \mathrm{T}$ limit and survive in the Paleocene.

\section{Mesoendothyrids (Plate 8.2 and Table 8.3)}

Some advanced mesoendothyrid genera (Plate 8.2; Table 8.3) like Biokovina, Cymbriaella, Dubrovnikella (Early to Middle Jurassic), or Zagrosella (Late Cretaceous) display clearly a heterochronic ontogenetic evolution, which (as for the orbitopsellids) can be interpreted as a recapitulation of characters (Haeckel). The introduction of innovations like multiple large porous apertures, pillars, and 
enlargement of uniserial-cylindrical or flattened adult chambers is interpreted as a peramorphosis (palingenesis of Haeckel) in terms of phyletic extension. The first chambers of Jurassic advanced forms diverging from the genus Mesoendothyra Dain retain the first steps of ancestral morphology of Paleozoic, Triassic or Liassic (Bassoullet et al. 2001) Endothyrids (Endoteba, Endotriadella). The fossil record in different areas of the Tethyan carbonate platforms, north and south (Briançonnais realm, Dinarids, Italy, etc.), points to a repetitive morphogenesis of these advanced more complicated forms (Biokovina-type and other close Middle Jurassic morphotypes) appearing at certain favorable periods (in terms of nutrients, light, etc.), or is limited to local favorable microenvironments. Major anoxic events or sea-level variations, etc. have no direct influence on these evolutionary steps. Clearly, new advanced taxa flourish between anoxic periods, e.g., the Orbitopsellids (LituoseptaOrbitopsella-Planisepta in the Middle Liassic, and Paleomayncina Table 8.6) with morphological transitions (Septfontaine 1988) and the bioseries MesoendothyraBiokovina. Besides, the later genus Labyrinthina (with a Lituosepta morphology) appears in the Late Jurassic, with a characteristic large planispiral nepionic stage. It is important to consider the large time gap (19 Ma, Toarcian to Callovian), which separates these two almost perfect homeomorphic genera, absent in thoroughly investigated carbonate deposits of Middle Jurassic age all around the Tethyan realm by many authors, as already stated by us (Septfontaine 1981). Still, this morphogenetic redundancy is not linked to any known abiotic event.

Paradoxically, secondary characters, like the "spinose" septal shape in equatorial section, are stable all along Mesozoic times. This "spinose, rose thorn" trait (a Late Paleozoic and Triassic heritage) disappears probably at the K/T limit, and is not recorded during Tertiary times. The combination of characters, the thick wall with pseudokeriotheca-to-alveolae (with transitions, see Plate 8.3) - strepto to planispiral coiling becoming uncoiled-cylindrical in the adult stage-basal-to-central-tomultiple-areal apertures, and finally the "spinose" septa in the equatorial section, permit definition of the mesoendothyrids. The relative importance (weight) of these different characters remains debatable from a taxonomic perspective.

The main Early Jurassic abiotic events triggering extinction and renewal of foraminifera populations is the T/J (CAMP, Atlantic magmatism) anoxic crisis combined with a marine regression (Wignall 2001). However, some simple (small) morphological types like some endothyrids-mesoendothyrids (Plate 8.2 (1-9)) survive these major environmental perturbations. They represent a primitive stock of forms from which larger and more complex populations diverge sporadically. The first adaptive radiation (red flame symbol) is recorded in the Pliensbachian, starting in the Late Sinemurian after a period of warming events (Table 8.3, yellow band, 1-4, red flame symbol), with the first complex morphotype Lituosepta (radial partitions), including the "Planisepta" flat morphotype (discussed by Fugagnoli and Bassi (2015)), which is a true valid genus as a concurrent to Orbitopsella in the Carixian, becoming the only survivor in the Domerian (biozone D, see Table 8.6). Biokovina, a large and complex variant of the genus Mesoendothyra ("Bosniella") was also recorded during this period of favorable environmental conditions (white band in Table 8.3). They all disappeared during the Late Domerian, as victims of a 


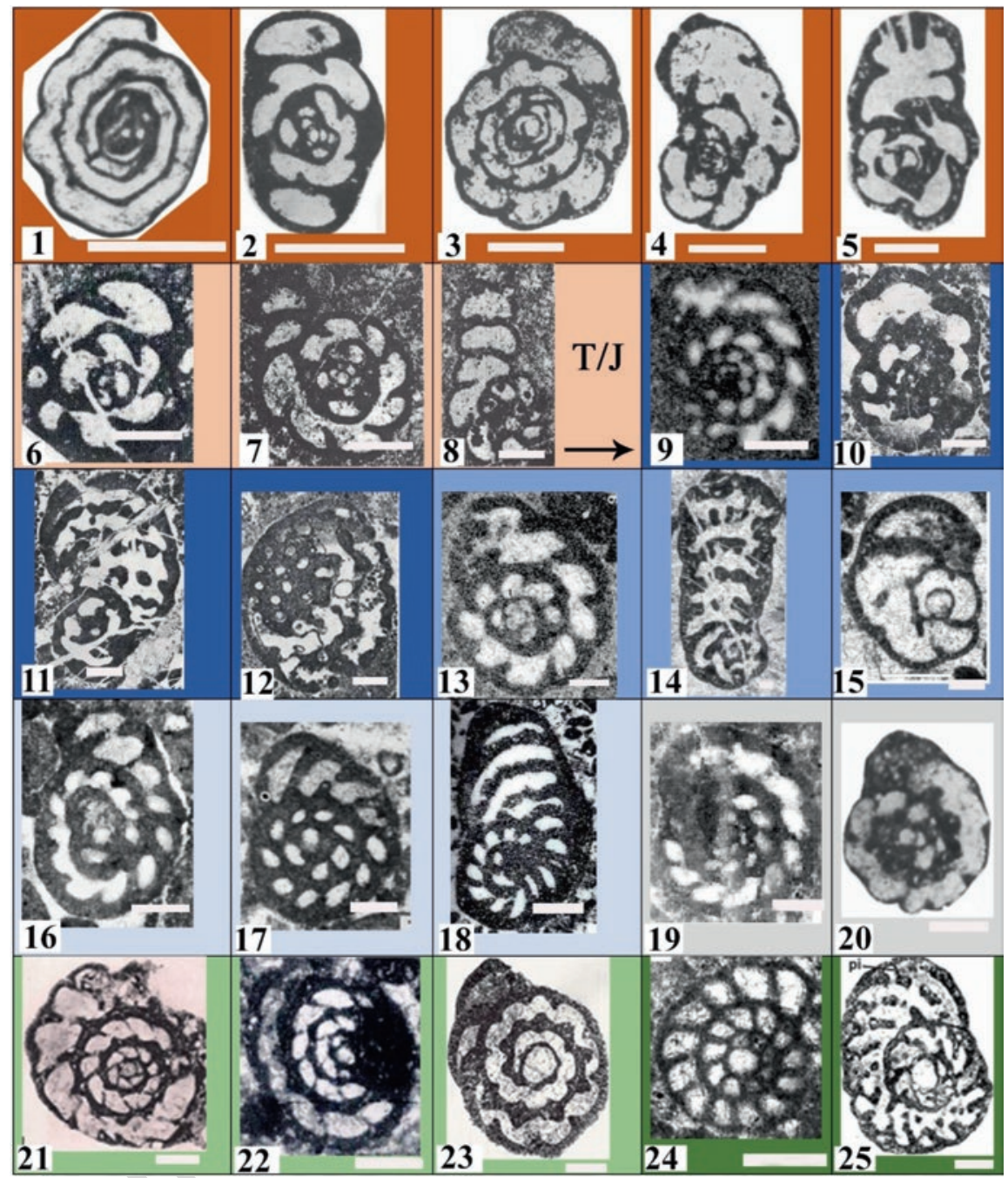

Plate 8.2 Comparison of different "crisis resilient" simple morphotypes among endothyridsmesoendothyrids. More complicated Mesozoic advanced morphotypes (commonly of larger size) are displayed (11-25). They all share some characters of the endothyrids (microstructure of the wall, septa shape "rose thorn," etc., see text) including primitive ancestral forms in the Late Paleozoic (Tournayellidae) to advanced descents in the Mesozoic around the genera Mesoendothyra and Everticyclammina (Table 8.3). The transition from pseudokeriotheca to an alveolar wall is obvious in advanced forms like Cymbriaella or Dubrovnikella

Scale bar: $0.250 \mathrm{~mm}$

(1-5. Brown: Late Paleozoic, excerpt from Loeblich and Tappan 1988)

1. Costayella (Tournayellidae)

2. Endochernella (Tournayellidae)

3. Eblanaia (Tournayellidae) 
4. Rectoavesnella (Tournayellidae) morphotype Everticyclammina (Mesozoic isomorph)

5. Haplophragmella (Endothyridae)

(6-8. Light brown: Triassic, excerpt from Zaninetti et al. 1972)

6. Endoteba (Endotebidae)

7, 8. Endotriadella (Endothyracea)

(9-12. Dark blue: Liassic, 9: excerpt from Septfontaine 1984b; 10-12: from Gusic 1977)

9. Mesoendothyra sp. (Mesoendothyridae)

10. Bosniella (advanced Mesoendothyridae)

11. Biokovina (advanced Mesoendothyridae)

12. Biokovina (advanced Mesoendothyridae)

(13-15 Middle blue: Dogger; 13: excerpt from Azeredo 1999; 14, 15: from Schlagintweit and Velić 2011)

13. Mesoendothyra (Mesoendothyridae)

14. Cymbriaella (advanced Mesoendothyridae, alveolae)

15. Dubrovnikella (advanced Mesoendothyridae, alveolae)

(16-18 Light blue: Bathonian; excerpt from Furrer and Septfontaine 1977)

16. Mesoendothyra (advanced Mesoendothyridae)

17. Mesoendothyra (advanced Mesoendothyridae, planispiral, thick wall)

18. Mesoendothyra (advanced Mesoendothyridae, uncoiled adult stage with multiple apertures; the Biokovina stage with interseptal pillars is not developed)

(19, 20 Light grey: Malm; 19 excerpt from Tasli 2001; 20 excerpt from Loeblich and Tappan 1988)

19. Karaisella $=$ Charentia (Mesoendothyrid)

20. Karaisella $=$ Everticyclammina $($ Everticyclamminid $)$

(21-23 Light green: Early Cretaceous; 21 excerpt from Hottinger 1967; 22 excerpt from Neumann 1967; 23 excerpt from Brönnimann and Conrad 1967)

21. Charentia (Mesoendothyrid)

22. Hemicyclammina (Mesoendothyrid)

23. Melathrokerion (Mesoendothyrid)

(24, 25 Dark green: Late Cretaceous; 24 excerpt from Sari et al. 2009; 25 excerpt from Schlagintweit and Rashidi 2017b)

24. Moncharmontia or Fleuryana (Mesoendothyrid)

25. Zagrosella, $\mathrm{pi}=$ pillar (Mesoendothyrid)

new environmental crisis (T-OAE 5-6). First simple everticyclamminids with general characters of mesoendothyrids but a slit-like aperture issue in the Lower Liassic persist through the all Mesozoic.

A second period of diversification (Middle Jurassic) can be observed following the environmental crisis of Toarcian-to-Aalenian times on the Apulian plate, Italy, and the Dinarids (Gusic 1977; Velic 2007) and in the Briançonnais realm. However, it is not known if these remarkable steps in morphological diversification are local adaptive variations (increasing the symbiotic culture in the "greenhouse farm" of symbiotic microorganisms), or have a larger repartition through the Tethyan carbonate platforms during favorable environmental conditions (time estimated at one or two stages). In spite of a bad fossil record, we still believe that the second hypothesis is the correct one.

Diversification is low during the Late Jurassic. The basic simple ancestor morphotype Mesoendothyra is still commonly represented, with the advanced genus Labyrinthina displaying a Lituosepta type of internal microstructure (homeomorphy in the same clade). This is not a "retrograde evolution" sensu Guex (2016), as 
the last orbitopsellids were already extinct $20 \mathrm{Ma}$ ago, but the reappearance of a complicated morphotype in the mesoendothyrid lineage.

During the Cretaceous, mesoendothyrids are well represented by various genera, like Melathrokerion and Debarina (modified porous aperture) along with the everticyclamminids (with coarse alveolae and a single-slit aperture). Both clades share the same basic characters, general or secondary, as described for Mesoendothyra. The relation between environmental climatic crisis as the Mid-Cretaceous events (8-10 in Table 8.3) is not clear as the Mesoendothyra morphotype is a rather ubiquitous and easily adaptive form in different hostile environments till the Late Cretaceous. The genus Zagrosella is a probable isomorph of Biokovina according to Schlagintweit and Rashidi (2017b). This last mesoendothyrid is not affected by the anoxic crisis but the end-Cretaceous events (cooling and warming, etc., Punekar et al. 2015) mark the demise of this otherwise tolerant morphological group.

\section{Valvulinids (Plate 8.3 and Table 8.4)}

This morphogroup of trochospiral foraminifera is characterized by a triserial arrangement of the chambers, with a conspicuous horizontal septal flap or "valvular tooth plate" covering partly the umbilicus and the interiomarginal (basal) slit aperture, an Early Dogger innovation. The complications (pillars) associated with the "tooth plate" or septal flap and the basal or areal multiple porous apertures can form a "trematophore-like" plate. The position and number of pores on or around the plate, also called a "sieve plate" by Loeblich and Tappan (1964), could be interpreted as an example of epigenesis as these variations were observed in a single synchronous population (commonly observed by the author in Middle Jurassic assemblages and recorded in the Eocene according to Neumann (1967), Fig. 150, see top of Table 8.4). These variations in a single population could reflect an adaptation to different types of microenvironments. The complications of the apertural face (in advanced morphotypes) have also a phylogenetical meaning, representing an iterative evolutionary trend independent of any major abiotic event.

The valvulinids are absent on the Triassic and Liassic carbonate platforms. Instead trochospiral triserial-to-multiserial microgranular morphotypes (also bearing a pseudokeriotheca) are represented by the siphovalvulinids-pfenderinids (Table 8.5). The ancestor group of the later valvulinids, abundantly recorded in Middle Jurassic to Cretaceous and Tertiary beds, is not known. A morphological relationship between septal flap and central columellar structure of the siphovalvulinids is possible. This would imply a structural deformation of the adaxial side of the hollow vertical columella of Liassic siphovalvulinids into a horizontal septal flap covering the umbilic. Such a morphological trend is not yet clearly documented (work in progress).

\footnotetext{
${ }^{4}$ Not equivalent to the vertical half tube or "tooth plate" of Hofker (1963).
} 
The first Middle-to-Late Jurassic valvulinids (praevalvulinids $*^{5}$ ) and Cretaceous chrysalidinids were already thoroughly studied by Banner et al. (1991). It is important to note that usually secondary characters, like septal convexity, which could at first glance be attributed to simple ecophenotypic variations among a synchronous population, can be an evolutionary signature and trend as well, allowing distinguishing Jurassic praevalvulinids* (flat to concave to slightly convex septa) and advanced Cretaceous isomorphic chrysalidinids (strongly convex septa).

The genus Cantabriconus (Schlagintweit and Rashidi 2017a) is an Early Cretaceous (Aptian) isomorph of the Paravalvulina-Parurgonina "plexus" belonging to the valvulinids. This later morphotype displays a horizontal "valvular tooth plate" modified in an apertural (uniserial) porous plate with pillars in adult chambers. It is, however, tentatively placed with the pfenderinids (Table 8.5) because of the early nepionic ontogenetic stage showing a large open umbilicus and distal (retro) deformation of the septa forming a central tube or straight columella.

\section{Pfenderinids (Plate 8.4 and Table 8.5)}

Triassic ancestral forms of the pfenderinids (Siphovalvulinidae) morphotypes and valvulinids (praevalvulinids) may be of the Turriglomina-Turritellella type (undivided twisted tube) or the three-chambered Trochammina type; these isomorphic taxa display a central columella or siphon. After the end Triassic anoxic crisis and global extinction, the evolutionary link between the first Siphovalvulinidae (Gale et al. 2018) and more advanced pfenderinids (and probably the later valvulinids) seems obvious considering the highly plastic variability of the deformed septa, forming a variable open half-columella (hollow or pillars filled) or umbilical siphon (Plate 8.5). The vertical adaxial part of the chamber's wall (against the spiral axis) appears in the axial section (Plate 8.4, $(18,19)$; Table $8.5(\mathrm{~A}-\mathrm{C}))$, directed in a backward position against the previous whorl and coated to it. This disposition of the successive chamber's wall leaves a clear central umbilical columella (siphon), which can be filled lately by pillars or calcitic material. Another possible modification (convergent to the valvulinid architecture) is the hypothetical transformation of the vertical wall of the columella (adaxial wall of the chambers) into consecutive horizontal septal flaps arranged in successive apertural porous septal plates joined by pillars plus secreted calcitic infill. The massive columella so formed can be secondarily dissolute, producing lately a groove or spiral canal in advanced pfenderinids of the Middle Jurassic and the Cretaceous.

Thus it may be difficult to differentiate the closely related valvulinids and pfenderinids in early evolutionary stages (Jurassic); the pfenderinids may be of polyphyletic origin. Only advanced forms show, respectively, the typical characters of each morphogroup. The presence of a siphon or a spiral canal or grooves at the surface of the columella may serve as a direct way for the expulsion of larger size

\footnotetext{
${ }^{5}$ Asterisks point to informal terms like "Praevalvulinids*" including the Jurassic valvulinids as illustrated in Table 8.4 and Plate 8.4, a proposed new taxonomic term (work in progress).
} 


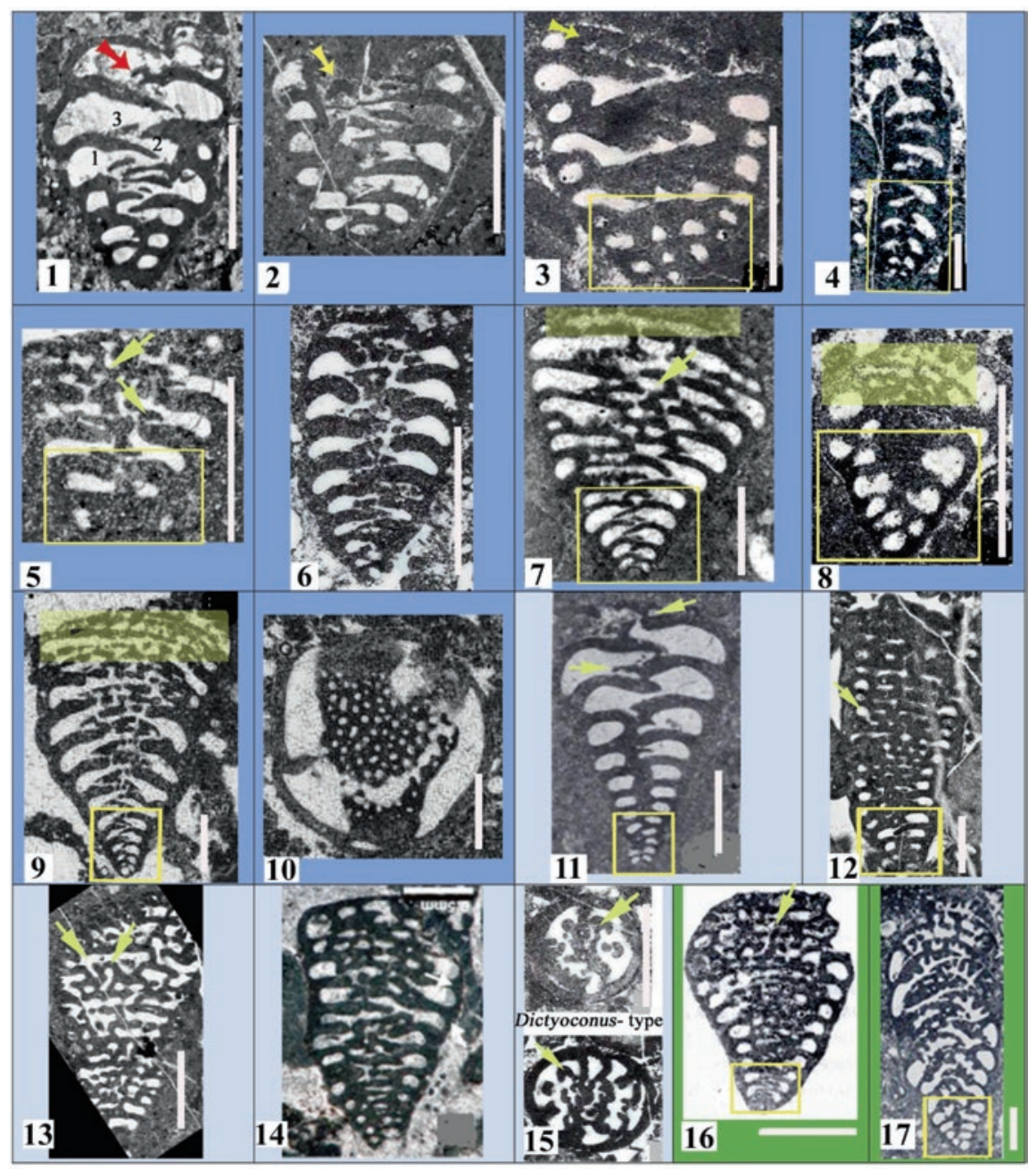

Plate 8.3 Valvulinids s.l., trochospiral-triserial morphotypes (1-17) characterized by a medium size (axial length 1.5-2 $\mathrm{mm}$ ) and a tooth plate with modifications (including Jurassic "praealvulinids*", Cretaceous chrysalidinids, and Tertiary valvulinids). A "crosswise oblique" stolon system is developed in advanced forms of "praevalvulinids*", a Bathonian innovation after the Early Jurassic anoxic crisis (Table 8.4). Note the Middle and Late Jurassic diversification of highly variable morphological populations (in space and time) of "praevalvulinids*" with flat to slightly convex septa (1-15, middle and light blue) and Middle Cretaceous chrysalidinids with arched strongly convex septa (16-17, green). The early ontogenetic stage of more advanced forms showing ancestor "praevalvulinid*" type of coiling is visible in the yellow rectangle (triserial test). Advanced taxa develop hemi-conical pillars (5-15) and multiple porous apertures in the center of adult chambers

Scale bar: ca $0.5 \mathrm{~mm}$

1-2. Praevalvulina* (Redmondoides) lugeoni. Note some deformations of the tooth plate (arrows) in the last three chambers 
3. Pseudomarssonella with numerous (4-5) chambers in the early stage (yellow rect.) and throughout

4. Praevalvulinid with triserial early stage (yellow rect.), becoming uncoiled uniserial in the adult with multiple cribrate aperture

5. Paravalvulina with conical pillars and the first known "crosswise oblique" stolon system in the Jurassic (yellow arrows, innovation)

6. Paravalvulina

(1-6, excerpt from Septfontaine 1988; 10, from Altiner and Septfontaine 1979)

7-14. Phylogenetically advanced morphotypes attributed to the genera Paravalvulina or Pseudomarssonella (8) with the transformation of the tooth plate in a very thin apertural plate covering completely the last chambers (7-9, yellow zone) in a uniserial arrangement. Some morphotypes (11) show a regular, simple morphology (triserial throughout) through the all Mesozoic with a tendency of complications (pillars, pores) in the last chambers (yellow arrows). These complications can appear already in the very first chambers (13-14) as an ontogenetic acceleration (7 excerpt from Azeredo 1999; 8 excerpt from Septfontaine 1981; 9, 10, excerpt from Velic 2007; 11, excerpt from Ramalho 2015; 12, 13 excerpt from Septfontaine 1981; 14, excerpt from Ples et al. 2015)

15. Parurgonina with hemi-conical pillars

(excerpt from Septfontaine 1988)

16. Paravalvulina ("Dukhania") or Accordiella; the new genus Cantabriconus (Schlagintweit and Rashidi 2017a), not figured here, belong to the same "plexus" of forms. The early stage shows already advanced traits (multiple apertures, yellow rect.)

(excerpt from Jones 2014)

17. Chrysalidina with typical arched septa. Juvenile part of the test: Valvulinid ancestor (yellow rect.)

(excerpt from Neumann 1967)

gamonts by the dynamic protoplasm flux (Hottinger 2006) and the construction of a new chamber.

Pfenderinids (advanced Pseudo-to-Paleopfenderina morphotypes) are absent from the Late Jurassic; the genus Chablaisia is the only representative in Oxfordian times with a spiral canal. Moreover, the trochospiral kurnubiids with a thick and opaque central columella (considered herein as a modification of the central siphon of Siphovalvulina in a porous plate with pillars and calcitic infill) are conspicuous and widespread along the margins of the Tethyan domain during late Jurassic times. The new clade appears earlier in the Middle Jurassic, with the small form Praekurnubia ancestor of the Late Jurassic larger Kurnubia and Conicokurnubia bioseries. The whole group shows an original innovation with the presence of a hypodermic network in the marginal zone of the chambers, the first known example in trochospirally arranged tests in the Jurassic, shared with the genus Pseudodictyopsella (Septfontaine and De Matos 1998) in the Bajocian of Oman and the Dinarids (Velic 2007). This novelty among trochospiral LIF is interpreted herein as tentatives (at least two) of a new association of LIF with larger symbiotic algae (dinoflagellates) succeeding to the probable symbiosis of pfenderinids-valvulinids 


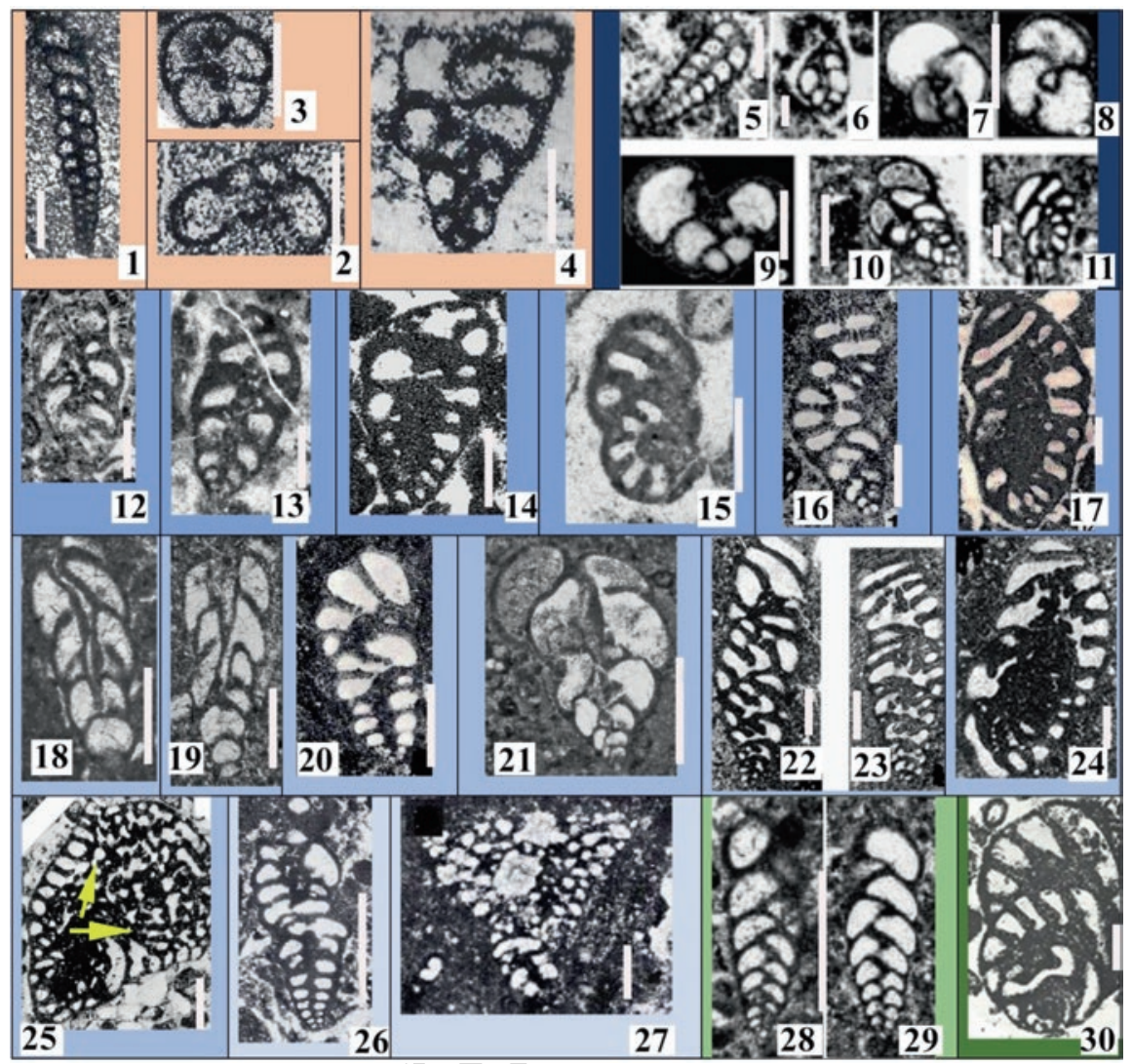

Plate 8.4 Siphovalvulinids to pfenderinids s.l. (Pseudopfenderina-Paleopfenderina-Pfenderina and allied Cretaceous forms, see Table 8.5 ); a very polymorphic group of trochospirally coiled (triserial to multiserial) small tests with a tendency to uncoil in the adult stage. The presence of a pseudokeriotheca is visible in some advanced genera with a thick wall, like the genus Paleopfenderina, but doubtful in other thin-walled morphotypes. In spite of great disparities in shape and number of chambers per whorl, the group shares a conspicuous general microstructure in the center of the chambers, well recognized by authors, but sometimes highly modified: a central siphon in primitive morphotypes (6-10) well developed in advanced forms $(18,19)$, which can be filled by secreted calcitic material and pillars forming an indistinct columellar mass $(14,15,17)$, which can be secondarily resorbed in a groove or spiral tunnel in advanced genera (30). The presence of small primitive siphovalvulinid morphotypes throughout the Mesozoic points to a possible example of a resilient simple morphotype (opportunist and possibly asymbiotic) against environmental crises in shallow water environments

Scale bar: ca $0.25 \mathrm{~mm}$

Light brown: Triassic

1. "Turritellella-Turriglommina" (undivided tube, with doubtful central siphon)

2. Trochammina

3. Trochammina

4. "Tetrataxis-Paleolituonella"

(1-4, excerpt from Zaninetti 1976)

Dark blue: Early Liassic 
5. Siphovalvulina var
6. Siphovalvulina var
7. Siphovalvulina var
8. Siphovalvulina var
9. Siphovalvulina var
10. Siphovalvulina var
11. aff. Pseudopfenderina
(5-11, excerpt from BouDagher and Bosence 2002)
Middle blue: Middle Liassic
12. aff. Pseudopfenderina
13. aff. Pseudopfenderina
14. aff. Pseudopfenderina
15. Pseudopfenderina (central button)
16. Advanced Siphovalvulina to Pseudopfenderina; uncoiled adult stage with porous aperture
17. Pseudopfenderina (typical axial section)
(12-17, excerpt from Septfontaine 1981, Septfontaine 1984b)
Light blue: Dogger (Bathonian)

18, 19. Siphovalvulina (elongated three-chambered morphotype, "half-moon" chambers with deformed backfolded septal tooth plate forming a partially closed central siphon)

20. Advanced Siphovalvulina morphotype (early chambers triserial) becoming multiserial in the adult with a porous aperture like (16)

21. Advanced Siphovalvulina var. (with resorption of the central siphon)

22, 23. Paleopfenderina var. (associated with more typical forms in the same thin section)

24. Paleopfenderina (typical subaxial section with some pillars visible and pseudokeriotheca)

25. Advanced Paleopfenderina (Conicopfenderina) with uncoiled discoid adult chambers, central pillars with a tendency to develop a "crosswise-oblique" stolon system (arrows) in a general orbitoliniform test

(18-20, excerpt from Septfontaine 1977, 1981; 21, excerpt from Granier et al. 2016; 22-24, excerpt from Septfontaine 1978)

Light blue-grey: Malm

26. Advanced Siphovalvulina (triserial throughout, with abnormal adult stage and central pillars, porous aperture)

27. "Neokilianina" (showing a Siphovalvulina early ontogenetic stage; later chambers divided into numerous arched chamberlets in a "crosswise-oblique" system; orbitoliniform test)

(27, excerpt from Ramalho 2015)

Green: Cretaceous

28, 29. Elongated typical Siphovalvulina var. (Belorussiella auct., with "half-moon-shaped" triserial chambers; the Late Cretaceous specimen is identical to the Jurassic morphotypes)

30. Classical advanced Pfenderina neocomiensis (with a central spiral tunnel formed by resorption of the central calcitic mass (or pillars); Early Cretaceous)

$(28,29$, excerpt from Kobayashi and Wernli 2014; 30 excerpt from Loeblich and Tappan 1964)

with bacterial filamentous microorganisms in the pseudokeriothecal wall, as shown

Smaller forms belonging to the siphovalvulinid ancestral genetic stock are still

True pfenderinids reappear in the Lower Cretaceous with the characteristic Pfenderina neocomiensis in the Berriasian (homeomorphic of Paleopfenderina) and 


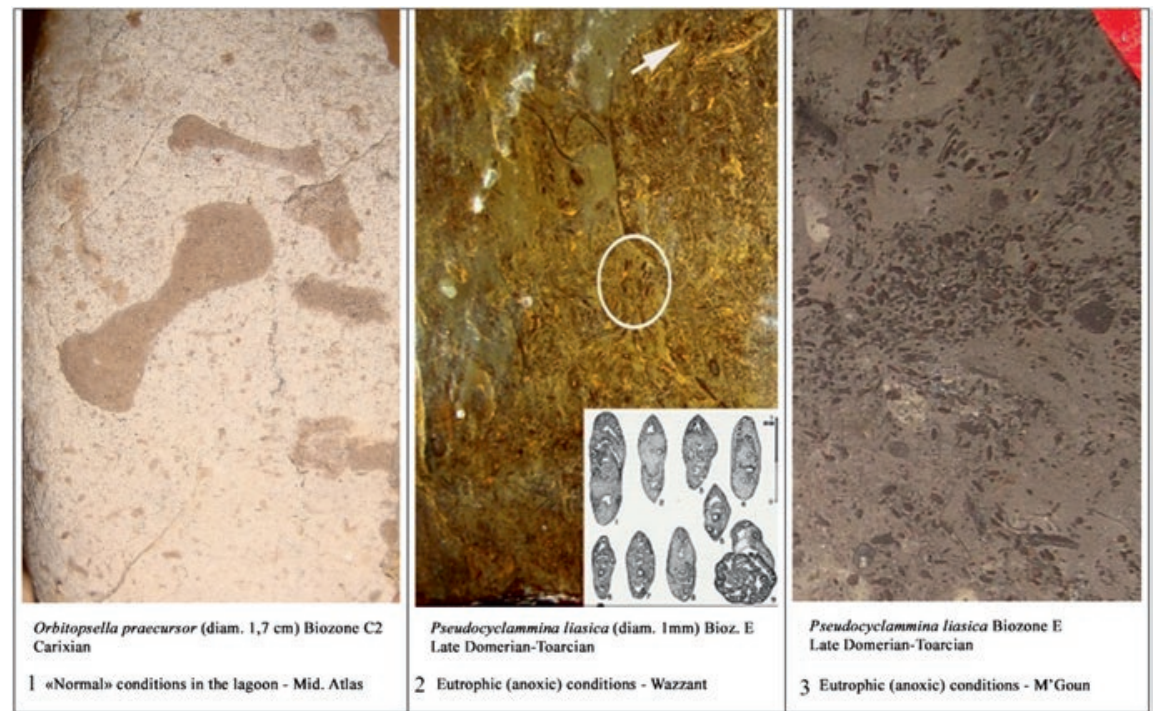

Plate 8.5 The Late Sinemurian to Domerian Aganane formation has registered the Late DomerianToarcian anoxic crisis visible on top, in the last tenth of meters (2-3) in a shallow water dark eutrophic carbonate facies arranged in metric parasequences. Specialized small-size and thin-shell dwellers are lithiotids and other Bivalvia (megalodontids etc., in biostromes), Gastropoda, and dwarf foraminifera (Haurania and Pseudocyclammina ("Paleocyclammina"). The macro- and microorganism populations are adapted to a eutrophic environment characterized by an olive-grey to black muddy (wackestone to packstone) facies. These unfavorable conditions (for larger orbitopsellids) contrast with the "normal," more oxygenated facies colored in clear yellow to light grey as shown in (1), the surface of an orbitopsellid bed of Carixian age

See also Table 8.6 for the stratigraphical setting

Axial sections of $P$. liasica visible on photo 2 (circle and arrow); drawings from Septfontaine (1984b); photos 1 and 2 same magnification; diam. Orbitopsella: $1.7 \mathrm{~cm}$; photo 3 slightly enlarged

other low trochospiral morphotypes during the Barremian attributed to P. globosa. Later in Middle Cretaceous times, these low trochospiral forms give rise to classical morphotypes attributed to "Nezzazatinella spp." or "Valvulammina picardi" by different authors. They all possess a central hollow columella with a spiral canal or a straight siphonal structure. It is important to note here that (apparently) secondary characters in these taxa, as the shape of chambers or the axial contour (rounded or angular) of the test, can be of prime importance for biostratigraphy. Thus angular periphery (in axial sections) of the "Nezzazatinella-type" can be considered an epigenetic innovation (ecophenotypic) during Middle Cretaceous times, unknown in the Jurassic and the Early Cretaceous, becoming later genetically fixed and conspicuous till the Maastrichtian (Septfontaine et al. 2019). Moreover, some advanced morphotypes (Cantabriconus with a siphovalvulinid early ontogenetic stage) in the Middle Cretaceous show uniserial chambers in the adult stage with an orbitoliniform test. The last pfenderinids s.l. (Pfenderinoidea) are diversified in the Maastrichtian and the Paleocene, with several genera and species as Pachycolumella 
spp., bearing a central hollow columella (Septfontaine et al. 2019) and the genus "Nezzazatinella" with an angular periphery, associated with ancestral siphovalvulinids. These Middle to Late Cretaceous and Paleocene representatives are grouped herein within two families: the Siphovalvulinidae (Gale et al. 2018), and the informal family "Neopfenderinidae*". The new genus Pachycolumella (homeomorph of the Liassic genus Radoicicina, Gale et al. 2018) is placed in the Siphovalvulinidae, and is represented by its two species elongata and acuta in the Maastrichtian, but the former (elongata) did not cross the K/T limit. However, P. acuta (a survivor) is abundant and morphologically diversified in Paleocene levels in Turkey (Sirel, 2015) and Iran.

\subsubsection{At a Shorter Time Scale, a Case History: The "Orbitopsellid" Model (Fig. 8.2; Table 8.6; Plate 8.5)}

The orbitopsellids (Lituosepta-Orbitopsella-Planisepta) on the Liassic carbonate platform of the central High Atlas in Morocco (Hottinger 1967; du Dresnay 1977; Septfontaine 1985) represent probably the best continuous record of morphological steps in a bioseries of larger foraminifera, here in the Aganane formation (Late Sinemurian to Pliensbachian) studied by Jenny (1988) and Crevello (1991). Other carbonate platforms around the Mesozoic Neotethys (e.g., Arabia, Oman, Adria, the Apennines) contain orbitopsellids as well. These platforms have a long history from the Triassic to the Cretaceous (Septfontaine and De Matos 1998; Cobianchi and Picotti 2001; Velic 2007; Husinec and Read 2007; Tisljar and Velic 1993; Ciocchini et al. 2008), recording hundreds of parasequences to third-order sequences in formations of thousands of meters thickness. However, the microfossil record in Liassic beds is often scarce or concentrated to some horizons only, due to facies variations and discontinuities.

In Morocco, the demise of the genus Orbitopsella (LAD of $O$. dubari or Cyclorbitopsella) occurs during the Late Carixian in a still constant (but cyclical) environment built of metric "shallowing upward" parasequences (Aganane formation, Jenny 1988). The first-order sedimentary sequences (Fig. 8.3) or elementary sequences of Strasser (2016) are related to the $20 \mathrm{kyr}$ precession cycles (in the allocyclic model). In this context, the morphological steps displayed in the LituoseptaOrbitopsella bioseries (Fig. 8.2) can be identified in terms of size variations (test and proloculus diameter increase) and internal morphological complications increase. After a bed-by-bed study in different locations (till the final extinction of the bioseries in a constant environment), a total of 24 stations (in green in Table 8.6) deliver abundant populations of Orbitopsella, permitting a rough statistical estimation of the mean diameter. A break in the mean diameter was clearly observed after a long period of stagnation, suggesting a punctuated mode of evolution of the mean size. This break is not related to exterior environmental changes, but recorded in the constant environmental setting characteristic of the Aganane formation (Fig. 8.3). 


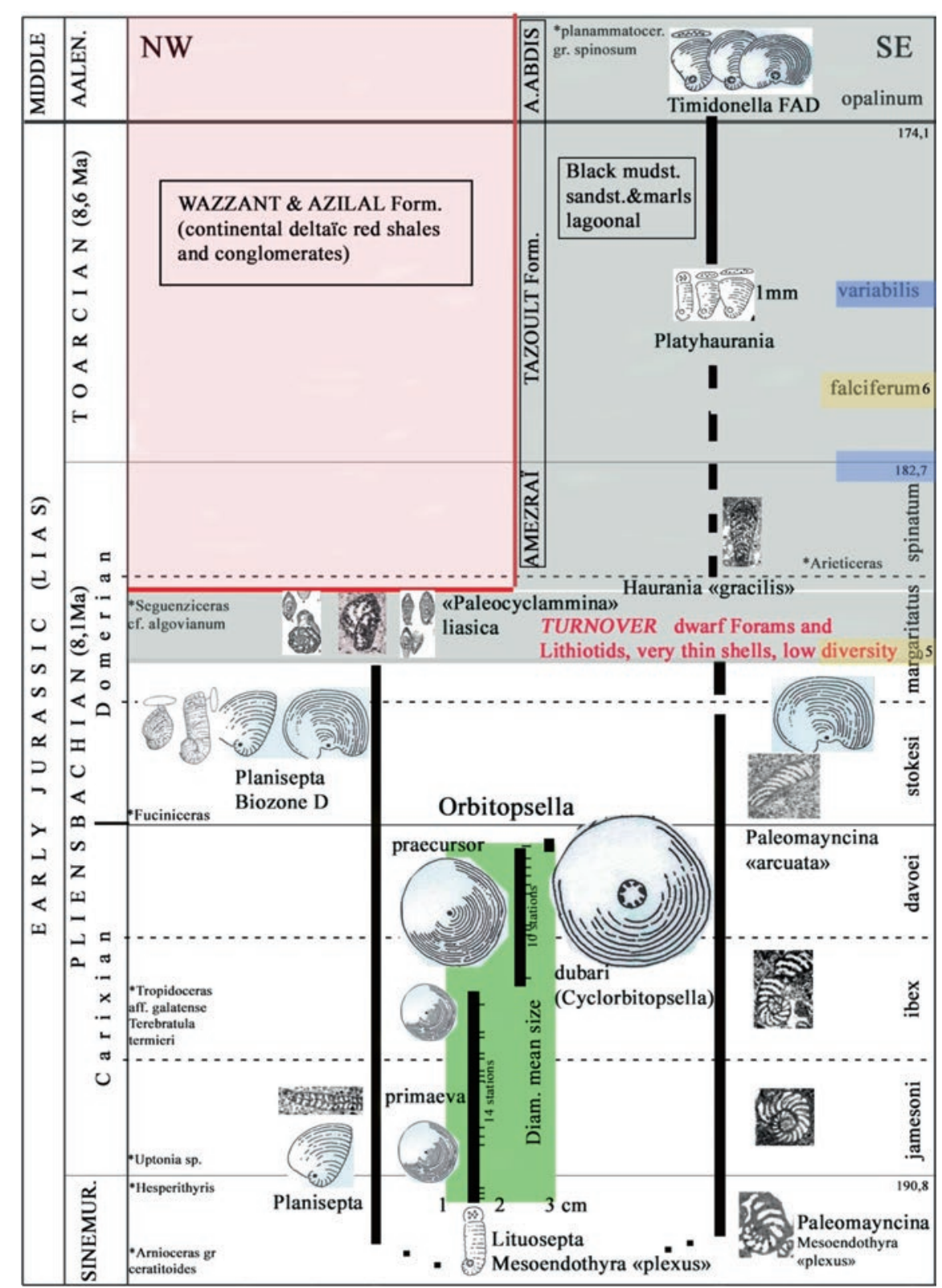

t6.5

Table 8.6 Growth and demise of "orbitopsellids s.l." (orbitopsellids s.str., and the Paleomayncina clade) and main OAE environmental crisis provoking a faunal turnover during the Middle Domerian (followed by the main T-OAE event in the falciferum-levisoni zone), which is consistent with the conclusions of Duarte et al. (2019) in Iberia for deeper water foraminifera)

The situation in the central High Atlas and Middle Atlas of Morocco (R'nim, Adoumaz, and Koumch sections) is figured in green; the fine horizontal dashed lines in green space: 14 sampling stations with $O$. primaeva and 10 stations with $O$. praecursor). The table shows the general stratigraphical setting and ammonite discoveries and control. Discussion in text 
The elementary cycles (shallow subtidal to inter- and supratidal) have no direct influence on the populations (or morphological variations) of foraminifera, which obviously find a "refuge" in a submerged area of the platform, migrating probably near the outer shelf during marine low-stand periods (Septfontaine 1985). This situation will last until the Early Domerian before the anoxic crisis registered on top of the Aganane formation (Plate 8.5).

Thus the rapid disappearance of large orbitopsellids during the Late Carixian in a more stable environment point rather to (1) an internal biological/genetical cause that may be related to a deterioration of the symbiotic relation becoming lethal for the host (Lefèvre et al. 2010), or the suppression of the sexual reproduction phase reducing morphological diversity (Hallock 1985), and (2) a mechanical cause related to the large diameter of the test which can no more afford a constant stability on the ground against storm or tidal current turbulences. We postulate that the attachment by pseudopods through the porous apertures situated on the peripheral side of the otherwise imperforate test offers a too weak anchorage for large shells with a diameter up to $2.5-3 \mathrm{~cm}$. However the smaller genus Planisepta (an isomorph of Orbitopsella already present as morphovariant of Lituosepta in the Late Sinemurian) persists, defining the D biozone (Septfontaine 1984b, 1988). But this new bioseries (test contour flabelliform to reniform in the last levels) could not reach the ultimate discoidal steps (d, e, Fig. 8.2), impeded by the Middle Domerian anoxic crisis, creating a drastic microfaunal turnover. Thus the LAD of the last orbitopsellid Planisepta (together with the LAD of the sister group Paleomayncina, biozone $\mathrm{D}$ in the Tethyan realm) is clearly due to a major climatic event and microfaunal turnover on top of the Aganane formation in the central High Atlas of Morocco, with deposition of olive-grey to black shallow water bioclastic limestones indicating anoxia (Plate 8.5). Dwarf or rare lithiotid bioherms are widespread in the Tethyan domain till Oman and the Himalayas (Wignall et al. 2006). During the long crisis period and aftermath (alternation of warm, 5-6 in tables, or cold anoxic events from the top Pliensbachian and the Toarcian to the Aaleno-Bajocian), a new microfaunal assemblage characterized by very small size (millimetric) and simple interior microstructure inhabited the eutrophic lagoons, Haurania "gracilis*" and "Paleocyclammina*" liasica, defining the biozone E, and later the very small discoid "fragile" genus Timidonella (biozone F) in the Aalenian-Bajocian. This foraminiferal turnover during the Middle Domerian (followed by the main T-OAE event in the falciferum-levisoni zone) is consistent with the conclusions of Duarte et al. (2019) in Iberia for deeper water foraminifera. The Late Liassic anoxic crisis was also recognized above the orbitopsellid LAD in Mallorca (Rosales et al. 2018). A similar situation with a drastic microfaunal faunal turnover following a climatic crisis event (anoxic OAE-2), at the Cenomanian-Turonian boundary, is described by Arriaga et al. (2016) in the Apennines (Italy). The survivor taxa are very small ("Lilliput effect"), with a simple architecture after the demise of larger discoid foraminifera. 


\subsection{Conclusions}

The variable mode of life and strategy of reproduction among foraminifera is a key for the understanding of the brutal response (demise) of LIF to severe environmental crises. When compared to the r-strategist planktonic foraminifera, with a high degree of variability and adaptation during anoxic periods (related to rapid reproduction rate), the larger benthic K-strategists with a slow reproduction rate impede rapid morphological changes and adaptation to new environmental conditions. Their highly specialized relation with specific endosymbionts (coevolution with symbiotic algae) conditions the internal architecture of the test in the marginal zone (size and shape of chamberlets) and the shape and size of the chamber itself (crescentic or cylindrical, to increase the volume of the "greenhouse" farm). Thus the ILFs are totally "padlocked" in their morphological characters. Such a situation is responsible for an unstable and fragile equilibrium in the changing environment of the carbonate platforms. Each lineage follows an analogous (parallel) irreversible way increasing the chamber volume. Contrary to planktonics, they are exposed to near-surface changes and perturbations (climatic, temperature, and sea-level variations, atmosphere composition, etc.) in the photic zone. Moreover, they are bottom dependent, with a vagile mode of life on the surface of an algal film (or algae), by contrast with the free-living planktonics in the water mass. Thus they have a very limited possibility to quit their biotope for better conditions in the photic zone during environmental stress periods. Moreover, the large size of discoid forms (gigantism) at the end of a bioseries may be inconvenient in terms of stability against currents and storms, provoking their extinction.

The mode of evolution appears definitely iterative for all groups considered here (Tables 8.1, 8.2, 8.3, 8.4, and 8.5). More advanced morphotypes in each clade appear several times (with slight modifications) throughout the Mesozoic, together with an increase of biodiversity during periods of favorable environmental conditions (Late Sinemurian to Early Domerian-Bajocian to Callovian-Late Jurassic to Early Cretaceous-Late Cretaceous), that is, between two main environmental crisis periods (anoxic events, global sea-level changes, etc.). More investigations are needed to assert this conclusion for specific morphogroups. Advanced morphotypes diverge from a stock of simple, primitive, smaller forms with long stratigraphical range and large adaptive possibilities (morphological plasticity) for each clade considered, acting as a "genetic memory." The large size and specialized architectural complications of advanced forms are obstacles to later morphological variations. The concept of "retrograde evolution" introduced by Guex (2016) seems to be a rather limited strategy present only in morphologically simpler planktonic microorganisms (planktonic foraminifera, Radiolaria, etc.) and some benthic forms (hyaline perforate foraminifera) affecting essentially secondary characters like ornamentation (e.g., keeled globotruncanids back to a smooth ancestor during stressful environmental periods), and uvigerinids, according to depth (ecophenotypes). These characters, considered epigenetic by Guex (2016), are absent in the unkeeled imperforate larger foraminifera (ILF) with a smooth test surface. 
The influence of abiotic events like anoxia concerns especially population composition as aftermath of extinction events. The new population is characterized by small, fragile forms, as stated after the Pliensbachian-Toarcian or the Late Cenomanian anoxic crisis. However, some simpler morphotypes like endothyrids and larger survivor morphotypes of lituolids (e.g., the hauraniids Broeckinella or Pachycolumella, a siphovalvulinid) cross the severe P/T crisis for the former, or the $\mathrm{K} / \mathrm{T}$ limit for the latter. This particularity remains unexplained.

Acknowledgments I am grateful to Professor John S. Torday for his help to improve the English of the last version of the manuscript.

\section{References}

Abramovich S, Almogi-Labin A, Benjamini C (1998) Decline of the Maastrichtian pelagic ecosystem based on planktonic foraminifera assemblage change: implication for the terminal Cretaceous faunal crisis. Geology 26(1):63-66

Altiner D, Septfontaine M (1979) Micropaléontologie, stratigraphie et environnement de déposition d'une série Jurassique à faciès de plate-forme de la région de Pinarbasi (Taurus Oriental, Turquie). Rev Micropaléontol 22(1):3-18

Archibald J-D, Clemens W et al (2010) Cretaceous extinctions: multiple causes. Science 328:973

Arriaga M-A, Frija G, Parente M, Caus E (2016) Benthic foraminifera in the aftermath of the Cenomanian-Turonian boundary extinction event in the carbonate platform facies of the southern Apennines (Italy). J Foraminiferal Res 46(1):9-24

Azeredo A-C (1999) Micropaleontologial studies on Middle Jurassic carbonate successions from the Lusitanian Basin (Portugal). Comun Inst Geol e Mineiro Portugal 86:59-84

Banner F-T, Simmons M-D, Whitaker J-E (1991) The Mesozoic chrysalidinidae (Foraminifera, Textulariacea) of the middle East: the Redmond (Aramco) taxa and their relatives. Bull Br Mus Nat Hist (Geol) 47(2):101-152

Bassoullet J-P (1997) Les grands foraminifères. In: Cariou, Hantzpergue (eds) Biostratigraphie du Jurassique Ouest Européen, Elf Mém. 17, p 293-304

Bassoullet J-P, Chabrier G, Fourcade E (1976) Données compémentaires sur la morphologie, la structure interne et la position stratigraphique de Timidonella sarda (Foraminifère, Lituolidae). Rev Micropaléontol 19(1):3-18

Bassoullet J-P, Boutakiout M, Vachard D (2001) D'éventuels foraminifères Fusulinina au Mésozoïque, à propos de la description d'Endotriadella ifranensis n.sp. dans le Lias du Maroc Comptes Rendus de l'Académie des Sciences, Série IIA. Earth Planet Sci 332(7):473-478

Bond D, Wignall P (2014) Large igneous provinces and mass extinctions: an update. Geol Soc Am Spec Paper 505:1-27

BouDagher-Fadel M, Bosence W.-J (2002) Early Jurassic benthic foraminiferal diversification and biozones in shallow-marine carbonates of western Tethys. Senckenberg lethaea 87(1):1-39

Bosence D, Procter E, AurelL M, Belkahla A, Boudagher-Fadel M, Casaglia F, Cirilli S, Mehdie M, Nieto L, Rey J, Scherreiks R, Soussi M, Waltham D (2009) A dominant tectonic signal in high-frequency, peritidal carbonate cycles? - a regional analysis of Liassic platforms from western Tethys. J Sediment Res 79:389-415

BouDagher M (2008) Evolution and geological significance of larger benthic foraminifera: the Mesozoic larger benthic foraminifera, the Jurassic. Dev Palaeontol Stratigr 21:544, Elsevier Ed

BouDagher M, Bosence D-W-J (2007) Early Jurassic benthic foraminiferal diversification and biozones in shallow-marine carbonates of western Tethys. Senckenb Lethaea 87(1):1-39 
Brasier M-D (1988) Foraminiferal extinction and ecological collapse during global biological events. In: Larwood GP (ed) Extinction and survival in the fossil record, The systematic association spec. vol. 34. Oxford Science Publ., Oxford, pp 37-64

Brönnimann P, Conrad M (1967) Cinquième note sur les Foraminifères du Crétacé inférieur de la région genevoise. Melathrokerion valserinensis, n.gen.,n.sp., un Framinifère nouveau du Barrémien à faciès urgonien dans le Jura français. CR Séances SPHN Genève NS 1(3):129-151

Burger B (2019) What caused Earth's largest mass extinction event? New evidence from the Permian-Triassic boundary in northeastern Utah. Global Planet Change, submitted pre-print manuscript, $59 \mathrm{p}$

Chaline J (1987) Paléontologie des vertébrés. Dunod Ed, Paris, 178 p

Cherchi A, Schroeder R (1975) Eclusia decastroy n. sp. (Lituolidae, foram.) del Barremiano della Sardegnia nord-occidentale. Soc Pal Ital Boll Modena 14(1):66-74

Ciocchini M, Chioccini RA, Didaskalou P, Potetti M (2008) Ricerche micropaleontologiche e biostratigrafiche sul Mesozoico della piattaforma carbonatica laziale-abruzzese (Italia centrale). Mem descr della Carta geol d'Italia 84:1-65

Cobianchi M, Picotti V (2001) Sedimentary and biological response to sea-level and palaeoceanographic changes of a lower-middle Jurassic Tethyan platform margin (Southern Alps, Italy). Palaeogeogr Palaeoclimatol Palaeoecol 169:219-244

Crevello P (1991) High-frequency carbonate cycles and stacking patterns: interplay of orbital forcing and subsidence on lower Jurassic rift platforms, High Atlas, Morocco. In: Franseen et al. (eds), Sedimentary modelling: computer simulations and methods for improved parameter definition, Kansas Geological Survey, 223, p 207-230

Cushmann J-A (1933) Foraminifera, their classification and economic use. Norwood Press Mass USA:349 $\mathrm{p}$

Darwin C (1859) The origin of species. John Murray London: $490 \mathrm{p}$

Davaud E, Septfontaine M (1995) Post-mortem onshore transportation of epiphytic foraminifera: recent example from the Tunisian coastline. J Sediment Res 65(1A):136-142

du Dresnay R (1977) Le milieu récifal fossile du Jurassique inférieur (Lias) dans le domaine des chaînes atlasiques du Maroc. 2d Symposium international sur les Coraux et récifs coralliens fossiles, Paris 1975. Mém. BRGM no 89, p 296-312

Duarte, et al. (2019) The Toarcian oceanic anoxic event at Peniche. An exercise in integrated stratigraphy-Stop 1.3. In: 2nd International Workshop on Toarcian Anoxic Event, Coimbra 2018, Portugal. IGCP Project 655. Field Trip Guidebook, p 33-54

Dustira A-M, Wignall P-B, Joachimsky M, Blomeier D, Hartkopf-Fröder C, Bond D (2013) Gradual onset of anoxia across the Permian-Triassic boundary in Svalbard, Norway. Palaeogeogr Palaeoclimatol Palaeoecol 374:303-313

Fleury J-J (2018) Rhapydioninidés du Campanien-Maastrichtien en région méditerranéenne: les genres Murciella, Sigalveolina n. gen. et Cyclopseudedomia. Carnets de Géologie 18(11):233-280

Föllmi K-B (2008) A synchronous, middle Early Aptian age for the demise of the Helvetic Urgonian platform related to the unfolding oceanic anoxic event 1a ("Selli event") Comment on the article "Sur la présence de grands foraminifères d'âge aptien supérieur dans l'Urgonien de la Nappe du Widhorn (Suisse centrale). Note préliminaire " by R.Schroeder, K.Schenk, A.Cherchi \& B.Schwitzer, Revue de Paléobiologie, 2007, 665-669. Revue de Paléobiologie Genève 27(2): 461-468

Font E, Adatte T, Planke S, Svensen H, Kürschner W-M (2016) Impact, volcanism, global changes and mass extinction. Palaeogeogr Palaeoclimatol Palaeoecol 441(1):1-3

Fugagnoli A, Bassi D (2015) Taxonomic and biostratigraphic reassessment of Lituosepta recoarensis CATI, 1959 (Foraminifera, Lituolacea). J Foraminiferal Res 45(4):402-412

Furrer U, Septfontaine M (1977) Nouvelles données biostratigraphiques (à l'aide des foraminifères) dans le Dogger à facies briançonnais des Préalpes médianes romandes. Eclogae Geol Helv 70(3):717-737 
Gale L, Barattolo F, Rettori R (2018) Morphometric approach to determination of lower Jurassic siphovalvulinid foraminifera. Res Paleontol Stratigr 124(2):265-282

Gould S-J (1977) Ontogeny and phylogeny. The Belknap Press, Harvard Univ. Press, Cambridge, $501 \mathrm{p}$

Granier B, Toland C, Gèze R, Azar D, Maksoud S (2016) Some steps toward a new story for the Jurassic-Cretaceous transition in Mount Lebanon. Carnets Geol 16(8):247-269

Guex J (2003) A generalization of Cope's rule. Bull de la Soc Geol France 174(5):449-452

Guex J (2016) Retrograde evolution during major extinction crisis. Springer, Heidelberg, 75 p

Gusic I, Velic I (1978) Lituolipora polymorpha n.gen, n sp. (Foraminiferida Lituolacea ?) from the Middle Liassic of the Outer Dinarids in Croatia and the establishment of a new family Lituoliporidae. Geol Vjesn Inst Geol istraz 30(1):73-93

Gusic Y (1977) A new foraminiferal family, Biokovinidae, from the Jurassic of the Dinarids and its phylogenetic relationships. Palaeont Jugosl 18:7-31

Hallam A, Wignall P (1999) Mass extinctions and sea level changes. Earth Sci Rev 48:217-250

Hallock P (1982) Evolution and extinction in larger foraminifera. Proc 3d North Am Paleontol Conv 1:221-225

Hallock P (1985) Why are larger foraminifera large? Paleobiology 11(2):195-208

Hennig W (1966) Phylogenetic systematics. Univ. of Illinois Press, Urbana, 263 p

Herman Y (1981) Causes of massive biotic extinctions and explosive evolutionary diversification through Phanerozoic time. Geology 9:104-108

Hofker J (1963) Studies on the genus Orbitolina (Foraminiferida). Thèse Leiden, Leiden

Hohenegger J (1994) Distribution of living larger foraminifera NW of Seseko-Jima, Okinawa, Japan. Mar Ecol 15(3/4):291-334

Hottinger L (1967) Foraminifères imperforés du Mésozoïque marocain. Notes Mém Serv Géol Maroc 209:1-168

Hottinger L (2006) The "face" of benthic foraminifera. Boll Soc Paleontol Italiana 45(1):75-89

Hottinger L, Caus E (1982) Marginoporiform structure in Ilerdorbis decussatus n. gen., n.sp. a Senonian agglutinated discoidal Foraminifer. Eclogae Geol Helv 75(3):807-819

Husinec A, Read JF (2007) The Late Jurassic Tithonian, a greenhouse phase in the Middle-Early Cretaceous "cool" mode: evidence from the cyclic Adriatic Platform, Croatia. Sedimentology $54: 317-337$

Jenkins H-C (1988) The Early Toarcian (Jurassic) anoxic event. Stratigraphic, sedimentary and geochemical evidence. Am J Sci 288:101-151

Jenny J (1988) Carte géologique du Maroc au 1:100.000 Azilal/Haut Atlas central-Mémoire explicatif. Notes et Mém du Service géol du Maroc 339:1-104

Jones R-W (2014) Foraminifera and their Applications. Cambridge Univ Press: 391p

Kaminsky M-A (2014) The year 2000 classification of the agglutinated foraminifera. In: Bubik M, Kaminsky M-A (eds) 2004 Proc. 6th Int. Workshop on Agglutinated foram. Grzybowski Found. Spec Publ, 8, p 237-255

Keller G, Adatte T, Pardo A, Bajpai S, Khosla A, Samant B (2010) Cretaceous extinctions: evidence overlooked. Sci Lett 328:974-975

Kobayashi F, Wernli R (2014) Early Cretaceous (Berriasian to Valanginian) foraminifers from the Torinosu limestone at the type locality of Sakawa, Shikoku,Japan. Revue de Paléobiologie Genève 33(1):67-78

Lecointre G, Le Guyader H (2001) Classification phylogénétique du vivant. Belin Ed, Paris, 560 p

Lee J-J, McEnery M-E, Kahn E-G (1979) Symbiosis and the evolution of larger foraminifera. Micropaleontology 25:118-140

Lefèvre T, Renaud F, Selosse M-A, Thomas F (2010) Evolution des interactions entre espèces: systèmes symbiotiques. In: Biologie évolutive. de boeck Ed., p 556-594

Loeblich A.-R, Tappan H (1964) Treatise on Invertebrate Paleontology, Part C, Protista 2 (vol. 1-2). Geol Soc of Amer, Univ Kansas Press

Loeblich AR, Tappan H (1988) Foraminiferal genera and their classification. Springer Science Ed., New York. (softcover reprint) 
Mac Leod N, Rawson PF, Forey PL, Banner FT, Boudagher-Fadel MK, Brown PR, Burnett JA, Chambers P, Culver S, Evans SE, Jeffery C, Kaminsky MA, Lord AR, Milner AC, Milner AR, Morris E, Owen B, Rosen BR, Smith AB, Taylor PD, Urquhart E, Young JR (1997) The Cretaceous-Tertiary biotic transition. J Geol Soc London 154:265-292

MacGillavry H-J (1978) Foraminifera and parallel evolution. How or why? Geol en Mijnb 57(3):385-394

Metodiev LS, Savov IP, Gröcke D-R, Wignall P-B et al (2012) Upper Pliensbachian-Toarcian palaeoenvironmental perturbations-belemnite isotopes Bulgaria. Solid Earth Discuss 4:315-361

Mikhalevitch V-I (2013) New insight into the systematics and evolution of the foraminifera. Micropaleontology 59(6):493-527

Neumann M (1967) Manuel de micropaléontologie des foraminifères. Gauthier-Villars, Paris, 298 p

Ples G, Bucur I, Pâcurariu A (2015) Foraminiferal assemblages and facies associations in the Upper Jurassic carbonates from Ardeu unit (Metaliferi Mountains, Romania). Acta Pal Rom 11(2):43-57

Punekar J, Keller G, Khozyem H-M, Adatte T, Font E, Spangenberg J (2015) A multi-proxy approach to decode the end-cretaceous mass extinction. Palaeogeogr Palaeoclimatol Palaeoecol 441(1):116-136

Ramalho M (2015) Stratigraphic Micropaleontology of the Upper Jurassic neritic formations of Portugal and its Tethyan context . 1 The Algarve basin. Memorias Geologicas Lab Nac de Energia e Geologia Lisboa 35: $110 \mathrm{p}$

Richardson SL (2006) Endosymbiont-bleaching in epiphytic populations of Sorites dominicensis. Symbiosis 42:1-15

Richardson SL (2009) An overview of symbiont bleaching in the epiphytic foraminifera Sorites dominicensis. In: Lang et al. (ed) Proc. of the Smithsonian Marine Science Symposium, p 429-436

Richardson SL, Rützler K (1999) Bacterial endosymbionts in the agglutinating foraminifera Spiculidendron corallicolum Rützler and Richardson, 1996. Symbiosis 26:299-312

Rigaud S, Vachard D, Martini R (2014) Agglutinated versus microgranular foraminifers: end of a paradigm ?. J Syst Palaeontol 1-20

Rosales I, Barnolas A, Goy A, Sevillano A, Armendáriz M, López-Garcia J-M (2018) Isotope records $(\mathrm{C}-\mathrm{O}-\mathrm{Sr})$ of late Pliensbachian-early Toarcian environmental perturbations in the westernmost Tethys (Majorca Island, Spain). Palaeogeogr Palaeoclimatol Palaeoecol 497:168-185

Ross C-A (1974) Evolutionary and ecological significance of large, calcareous Foraminiferida (Protozoa). Great Barrier Reef Proc. 2d Int. Coral Reef Symp., vol. 1, p 327-333

Sari B, Tasli K, Özer S (2009) Benthonic Foraminiferal Biostratigraphy of the Upper Cretaceous (Middle Cenomanian-Coniacian) Sequences of the Bey Daglari Carbonate Platform, Western Taurides, Turkey. Turk J Earth Sci 18:393-425

Schlagintweit F, Velic I (2011) New and poorly known Middle Jurassic larger benthic foraminifera from the Karst Dinarides of Croatia. Geol Croatica 64(2):81-99

Schlagintweit F, Rashidi K (2017a) Persiacyclammina maastrichtiana n.gen., n. sp., a new larger benthic foraminifer from the Maastrichtian of Iran. Acta Palaeont Romaniae 13(1):15-23

Schlagintweit F, Rashidi K (2017b) Zagrosella rigaudi n. gen., n. sp., a new biokovinoidean foraminifer from the Maastrichtian of Iran. Acta Palaeont Romaniae 13(1):3-13

Schlagintweit F, Septfontaine M, Rashidi K (2019) Pseudochablaisia subglobosa gen. et sp. nov., a new pfenderinid foraminifera from the Upper Cretaceous of Iran.

Cretaceous Research 100:105-113

Septfontaine M (1971) Eclusia moutyi gen. et sp. nov., un foraminifère nouveau du Valanginien du Jura méridional. Arch Sci Genève 24(2):285-298

Septfontaine M (1977) Niveaux à foraminifères (Pfenderininae et Valvulininae) dans le Dogger des Préalpes médianes du Chablais occidental (Haute-Savoie, France). Eclogae geol Helv 70(3):599-625

Septfontaine M (1978) Chablaisia nov. gen., un nouveau genre de foraminifère du Jurassique briançonnais (nappe des Préalpes médianes. Arch Sci Genève 31(1):39-50 
Septfontaine M (1981) Les Foraminifères imperforés des milieux de plate-forme au Mésozoïque: détermination pratique, interprétation phylogénétique et utilisation biostratigraphique. Rev Micropaleontol 23(3/4):169-203

Septfontaine M (1984a) Le Dogger des Préalpes suisses et françaises-stratigraphie, évolution paléogéographique et paléotectonique. Mém Soc Helv Sci Nat 97:121

Septfontaine M (1984b) Biozonation (by means of imperforate foraminifera) of the liassic carbonate inner platform of the haut atlas (Morocco). Rev Micropaléontol 27(3):209-229

Septfontaine M (1985) Depositional environments and associated foraminifera (lituolids) in the Middle Liassic carbonate platform of Morocco. Rev Micropaléontol 28(4):265-289

Septfontaine M (1988) Vers une classification évolutive des Lituolidés (Foraminifères) jurassiques en milieu de plates-formes carbonatées. Rev Paléobiol vol. spéc. 2, Benthos'86, 229-256

Septfontaine M, De Matos E (1998) Pseudodictyopsella jurassica n. gen., n. sp. A new foraminifera from the Early Middle Jurassic of the Musandam Peninsula, N-Oman mountains; sedimentological and stratigraphical context. Rev Micropaléontol 41(1):71-87

Septfontaine M, Arnaud-Vanneau A, Bassoulet J-P, Gusic Y, Ramalho M, Velic I (1991) Les foraminifères imperforés des plates-formes carbonatées jurassiques: état des connaissances et perspectives d'avenir. Bull Soc Vaud Sci Nat 80(3):255-277

Septfontaine M, Schlagintweit F, Rashidi K (2019) Pachycolumella nov. gen., shallow-water benthic imperforate foraminifera and its species from the Maastrichtian and Paleocene of Iran. Micropaleontology 65(2):145-160

Sirel E (2015) Reference sections and key localities of the Paleogene stage and discussion C-T, P-E and E-O boundaries by the very shallow water foraminifera in Turkey. Ankara University Yayinlari, 461:171p

Song Y, Black G, Lipps H (1994) Morphological optimization in the largest living foraminifera: implication from finite element analysis. Palaeobiology 20(1):14-26

Strasser A (2016) Hiatuses and condensations: an estimation of time lost on a shallow carbonate platform. Deposit Rec J IAS (2015) 1(2):91-117

Strasser A, Caron M, Gjermeni M (2001) The Aptian, Albian and Cenomanian of rotter Sattel, Romandes Prealps, Switzerland: a high-resolution record of oceanographic changes. Cretaceous Res 22:173-199

Tasli K (2001) Benthic Foraminifera of the Upper Jurassic Platform Carbonate Sequence in the Aydincik (Icel) Area, Central Taurides, S Turkey. Geologia Croatica 54(1):1-13

Tisljar J, Velic I (1993) Upper Jurassic (Malm) shallow-water carbonates in the western Gorski Kotar area: facies and depositional environments (western Croatia). Geol Croatica 46(2):263-279

Vachard D, Munnecke A, Servais T (2004) New SEM observations of keriothecal walls: implications for the evolution of Fusulinida. J Foraminiferal Res 34(3):232-242

Van de Schrootbrugge B, Wignall PB (2016) A tale of two extinctions: converging end Permian and end Triassic scenarios. Geol Mag Cambridge 153:1-23

Velic I (2007) Stratigraphy and paleobiogeography of Mesozoic Benthic Foraminifera of the Karst Dinarids (SE Europa). Geol Croatica 60(1):1-113

Wignall P (2001) Large igneous provinces and mass extinctions. Earth Sci Rev 53(1-2):1-33

Wignall P, Benton (2000) Discussion on Lazarus taxa and fossil abundances at times of biotic crisis. J Geol Soc London 157:511-512

Wignall P, Racki G (2006) Mass extinctions, volcanism and anoxia: comparisons of the end Permian and Early Jurassic events. ISC 2006. In: 17th International Sedimentological Congress, Fukuoka, Japan. Abstract

Wignall PB, Hallam A, Newton RJ, Sha JG, Reeves E, Mattioli E, Crowley S (2006) An eastern 1137 (Tibetan) record of the Early Jurassic (Toarcian) mass extinction event. Geobiology 4:179-190

Zaninetti L (1976) Les Foraminifères du Trias-Essai de synthèse et corrélation entre les domaines mésogéens européen et asiatique. Riv Ital Pal 82(1):1-258

Zaninetti L, Brönnimann P, Baud A (1972) Microfacies particuliers et Foraminifères nouveaux de l'Anisien supérieur de la coupe du Rothorn (Préalpes médianes rigides, Diemtigtal, Suisse). Mitt Ges Geol Bergbaustud Innsbruck 21:465-498 